Portland State University

PDXScholar

Spring 7-18-2013

\title{
Life Post 9/11: Experiences of Korean Americans Ten Years Later
}

Jay Lee

Portland State University

Follow this and additional works at: https://pdxscholar.library.pdx.edu/open_access_etds

Part of the Christianity Commons, Critical and Cultural Studies Commons, and the Korean Studies Commons

Let us know how access to this document benefits you.

\section{Recommended Citation}

Lee, Jay, "Life Post 9/11: Experiences of Korean Americans Ten Years Later" (2013). Dissertations and Theses. Paper 1079.

https://doi.org/10.15760/etd.1079

This Thesis is brought to you for free and open access. It has been accepted for inclusion in Dissertations and Theses by an authorized administrator of PDXScholar. Please contact us if we can make this document more accessible: pdxscholar@pdx.edu. 


\title{
Life Post 9/11: Experiences of Korean Americans Ten Years Later
}

by

Jay Lee

A thesis submitted in partial fulfillment of the requirements for the degree of

\section{Master of Science}

in

Communication

\author{
Thesis Committee: \\ Susan Poulsen, Chair \\ Priya Kapoor \\ Christopher Carey
}

Portland State University

2013 
(C) 2013 Jay Lee 


\begin{abstract}
This is one of the first qualitative studies to investigate experiences of KoreanAmerican Christians living in New York City at the time of 9/11. This study sought to gain an understanding of how a group of Second Generation Korean-American Christians living in New York City at the time of the 9/11 attacks experienced that event and the event's impact on their religious beliefs. The study also investigated the communication context at the time of the ten year anniversary of the event, September $11^{\text {th }}, 2011$. The guiding research questions were: RQ1) What were their life experiences of 9/11? RQ2) Was their religious status affected by the event? RQ3) What is being communicated about $9 / 11$ after 10 years?
\end{abstract}

The research design was a phenomenological study that included eight individual interviews with second generation Korean-Americans who were 14-18 years of age at the time of the 9/11 attacks. Four initial macro level thematic patterns emerged: I: The day of the attack. II: Immediate Post 9/11. III: Religious Impact. IV: 9/11 Ten years later. Some key findings in the study included narratives of various emotional responses to the event, such as panic, disbelief, and fear. Age was significant, as participants recognized how their age during and after the event, impacted their lived experiences and understanding of 9/11. Location impacted participants and their loved ones. Each participant was in high school during 9/11 which affected ways of gathering information, the impact of seeing smoke coming from the World Trade Towers, and having poor cell phone reception. The study also revealed that two participants became more religious and active in the 
Christian church directly because of $9 / 11$, while the attitudes, beliefs, and practices of the other six participants were found to be unaffected by $9 / 11$. At the ten year anniversary of 9/11 safety in New York City and in U.S. post 9/11, 'feeling vulnerable' to attacks, and 9/11 being 'just another day' were among the issues addressed by participants. 


\section{ACKNOWLEDGEMENTS}

I am very grateful to have the opportunity to acknowledge the many individuals who have helped me along this long journey. First and foremost, I want to thank the members of my committee: Dr. Susan Poulsen, for your endless support and guidance on this thesis. Since the early days of my undergraduate career, you have always strived to make me not just a better student, but a better person. I will always cherish the many conversations we have had about this study, from the very beginning of brainstorming about thesis topics, to making those ideas into a thesis project. Thanks to Dr. Priya Kapoor, for your guidance, patience, and support throughout the process. This thesis would not have been possible without your energy, kindness, and dedication. Also thank you Dr. Christopher Carey, for your helpful advice and insightful thoughts related to the findings of this study. I am honored to have a diverse and supporting group of mentors.

I would also like to thank my parents for believing in my pursuit of higher education and offering constant support and love. I offer my thanks to my thesis partners Sara Kaufman and Stacy Austin, who provided useful feedback and suggestions. My

family and friends have always been an enduring source of strength and encouragement.

Last but not least, I would like to thank the participants in this study. This thesis study would have not been a real achievement without the courage and strength of the participants. Thank you for your time, honesty, integrity, and willingness to share your lived experiences with me. I hope this thesis honors you, your loved ones, and your 
experiences. I am deeply honored to be able to learn and grow from these meaningful conversations. 


\section{TABLE OF CONTENTS}

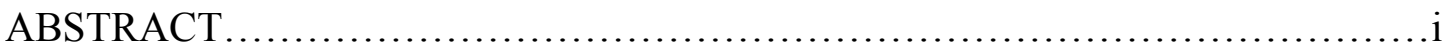

ACKNOWLEDGMENTS ........................................................

LIST OF FIGURES: ............................................................. CHAPTER I

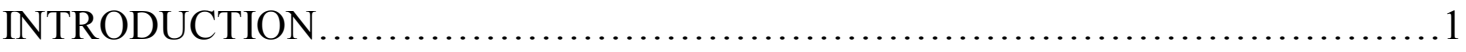

Purpose of study ........................................................

Background of study: Researcher Positionality.............................. 1

Research Questions..................................................

CHAPTER II

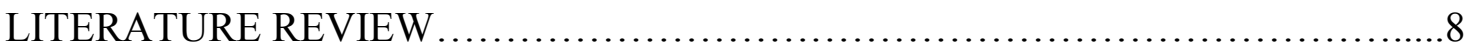

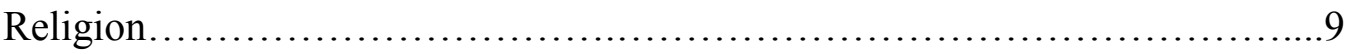

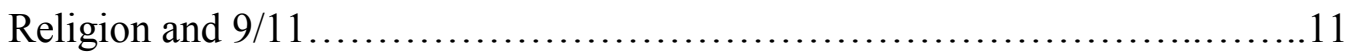

Second Generation Korean Americans and 9/11 ..........................22

CHAPTER III

METHODOLOGY AND RESEARCH DESIGN .................................25

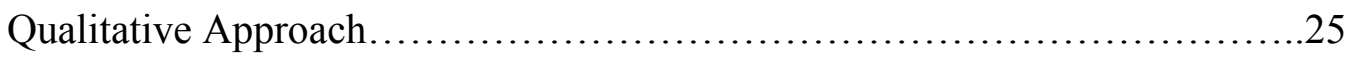

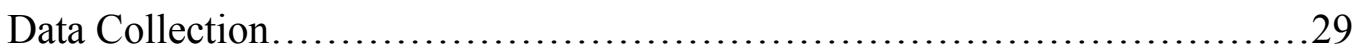

Explication of the data.................................................. 34

CHAPTER IV

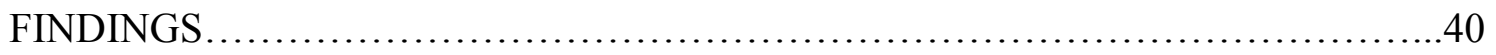

Demographic Characteristics.............................................. 40

Experiencing 9/11: Initial Themes and Patterns..............................41

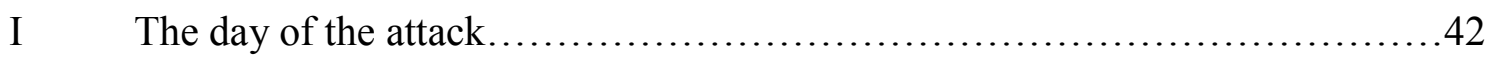

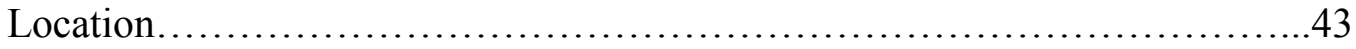


Age Factor......................................................45

Finding out....................................................47

Initial Experiences..............................................52

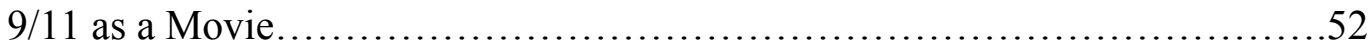

Chaotic and Confusing day.............................................53

Seeing the smoke.................................................56

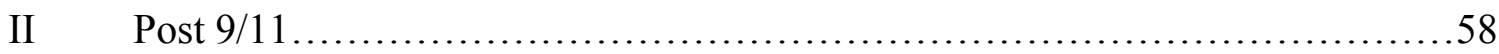

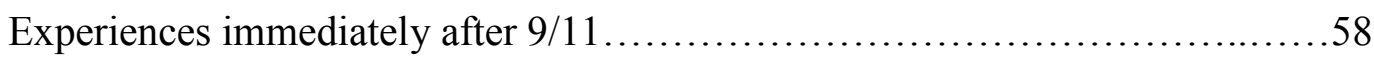

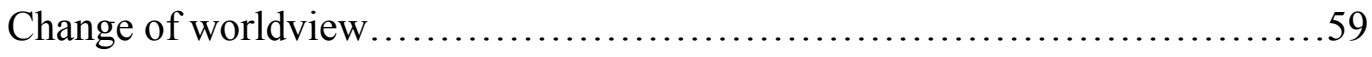

Personal Connection with the event......................................61

Coping..........................................................63

III Religion........................................................... 65

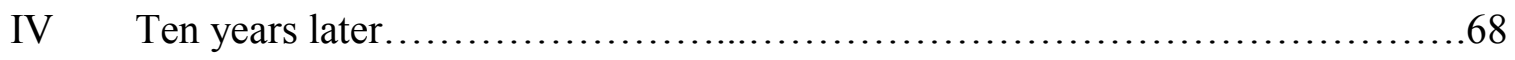

CHAPTER V

DISCUSSIONS AND CONCLUSION..................................73

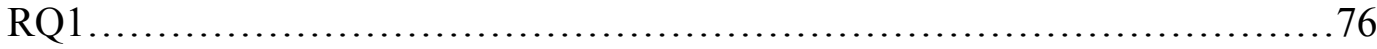

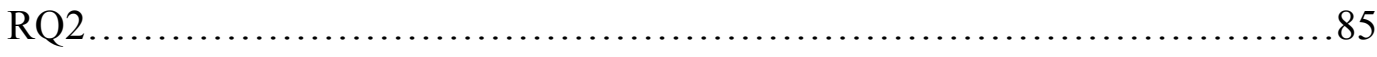

RQ3 ......................................................... 93

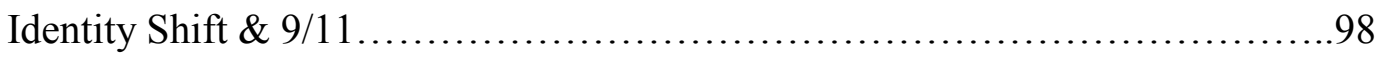

Research Expectations.............................................101

Limitations........................................................ 104

Contributions...................................................... 106

Future Research................................................107

Concluding Remarks.............................................. 107

REFERENCES........................................................ 109

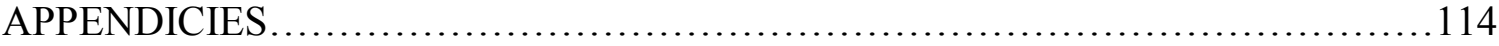


A Interview Guide.................................................... 114

B Informed Consent..................................................... 16

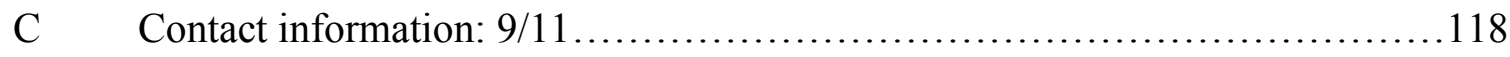




\section{LIST OF FIGURES}

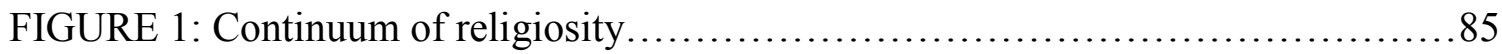




\section{CHAPTER I}

\section{INRODUCTION}

\section{PURPOSE OF STUDY}

The purpose of this qualitative study was to gain insight into and understanding of the lived experiences of a group of second generation Korean-American Christians who

were present in New York City at the time of the attacks, September $11^{\text {th }}, 2001$. As a way of marking the tenth anniversary of the event, I traveled back to my hometown, Staten Island, New York, and conducted semi-structured interviews with eight previous church members. The resulting data were based on their lived experiences of $9 / 11$, the relationship between the event and their religious beliefs, and what was communicated by them about $9 / 11$, ten years later.

\section{BACKGROUND FOR THE STUDY: RESEARCHER POSITIONALITY}

My interest in this topic begins from my own personal story of September $11^{\text {th }}$, 2001 and like thousands of others in New York City and worldwide, I became a victim of 9/11. The terrorist attack on September $11^{\text {th }}, 2001$, has had a profound impact on my life. It was a day that will never be forgotten and like for millions across the world, I still remember where I was during $9 / 11$. That particular day was a crucial turning point for my world view perspective and religion.

I was born and raised in Staten Island, New York until the age of eighteen. To this very day, I take great pride in being a native New Yorker. I lived on the northeast side of 
Staten Island which is about a twenty five minute boat ride (the Staten Island Ferry) to and from downtown Manhattan. I was fifteen years old and in school the day the attack occurred. Just barely into the first class period, there were the initial reports being broadcast via the school's loud-speaker of a small plane flying low near Manhattan. I recall joking around with friends saying what kind of idiot can fly a plane near downtown" not realizing the seriousness of the experience until the event unfolded throughout the day. I was sitting in second period class when the first plane crashed into one of the World Trade Center buildings (WTC). On that particular day I sat at the back of the classroom, closest to the windows and had a good view of downtown Manhattan. Almost immediately after the first plane hit, I recall looking towards downtown and seeing large, thick, dark clouds starting to form in the sky from the burning buildings. It was at that point when things started to become chaotic and the surrounding environment changed dramatically. I recall students running from classroom to classroom trying to find out what was going on. Some students were crying and it seemed like everyone was trying to contact loved ones.

The principal of the high school was on the loud-speaker, informing the faculty and students not to panic and to stay calm. He then slowly began calling the names students, informing them to go to the auditorium because their parents had arrived to pick them up. I remember after the second plane hit the other twin towers, the lists of student names became longer and seemed to never stop. By the end of second period class, the high school went to lock-down mode and no student could leave the school without permission. The idea of having parents coming to pick their children up from school was 
not a possibility for me because my parents worked in downtown Manhattan and were literally blocks away from the WTC. So not only did I know that no one was coming to get me safely out of school, I also did not know the status and whereabouts of my parents.

For almost ten years, my parents owned a small tourist store which was located at $16^{\text {th }}$ Beaver Street in downtown Manhattan. More specifically, it was connected to Wall Street and was located just two blocks south of the World Trade Center. To this day, I have great childhood memories of traveling in and around the World Trade Center. Never would I have imagined that the twin buildings would no longer stand after that day. I was told later by my parents that during the attacks, my father refused to close the store because they were busy selling merchandise! My father said at the beginning of the attacks, he saw it as a good opportunity to make sales and money. I was told that while the towers were burning, all of the disposable cameras were sold and people bought other necessities from our store, such as batteries and telephone calling cards. In the attempt to make a financial gain, my parents chose to stay at the store and sell out whatever they could. Because of the store's proximity to the WTC, when the twin buildings collapsed, debris and smoke traveled into the store. Like the streets of downtown, after the buildings fell, the store was covered by debris and smoke. I was told by my mother that the debris from the fallen buildings reached up to her ankle. Thankfully, my parents survived the attacks without any physical harm.

In the weeks that followed 9/11, a large portion of downtown would be blocked off for recovery and cleaning purposes. My parents were not allowed to return to the store 
for nearly a month after 9/11. The tourist economy in New York City was greatly affected by attacks. Our business relied heavily on tourists and high traffic flow in the downtown area. I was told by my father that a portion of their customers either passed away that day or packed up and moved somewhere else. After trying to financially survive for the next two years, my parents decided to close the store and start a new life on the west coast. I ended up moving to Portland, Oregon in 2004.

Immediately after the event, I reflected upon my Christian faith and spent much of my spare time at Marn Baek Sung (MBS) church to mourn and find closure for what had occurred. I was emotionally drained and could not find answers as to why this attack took place. I was frustrated and bitter because no matter what anyone said to me, nothing justified what happened that day. Confused and angry, I questioned my faith and belief in Christ. Before moving to Portland, I left Christianity altogether.

It was on that particular day, more than ten years ago, that my life completely changed and I have not been the same since. It was because of the attacks that my parents lost their business and it was due to the event that I challenged and changed my core religious beliefs. The event changed my worldview; for the first time in my life, I experienced the reality of global terrorism. For what seemed like a distant concept to be only seen on TV or online, warfare and terrorism became real to me, brought to my front door step.

The idea of this thesis project began somewhat unintentionally in 2004 with my admission to Portland State University as an undergraduate student. I wrote a letter to the 
university about my life experience as teenager growing up in New York City, having witnessed 9/11 and how it impacted my life. Little did I know the admission letter was the beginning path of inquiry that would eventually lead me to graduate school in search of stories of 9/11, how the event impacted my previous church members, and their transformation over time. For years I found myself asking: - Wat were other church member‘s experiences of 9/11? Did they have the same perspective as I did? Did 9/11 change their thoughts on Christianity and religion? What do they think about the ten year anniversary?" I wanted to know what Marn Beak Sung church members experienced during and after $9 / 11$.

In preparing for this study I identified my current perspective about the eventual encounters with the informants who agreed to meet with me. I believed that each informant was somehow impacted by the events of $9 / 11$ and being a part of this particular group, I knew ahead of time that each informant was present in New York City during 9/11. I believed that each informant would truthfully disclose their experiences with me throughout the interviewing process and that the informants had nothing to hide.

I purposely choose to disclose my personal experiences of $9 / 11$ after the interviews were completed. I did not want the informants to realize how the event negatively impacted my life prior to conducting the interviews. It could have potentially hindered the interviewing process and affected the informants.

Specific to the research process I expected to interview a total of eight former Marn Baek Sung members and I expected that the interviews would take place at the 
Marn Baek Sung church. I thought the interviews would be about an hour and a half in length and I prepared for a long interview. I also expected a special service would be held at Marn Beak Sung church on the ten year anniversary date of 9/11. I expected that there was some kind of religious change for most of the informants directly due to $9 / 11$. I also thought this was going to be a sensitive topic for some informants, so I took precautionary measures and made a contact sheet with several resources for the informants. The contact sheet included several websites and phone numbers to contact professional help or resources to share their experiences as needed.

While writing, I understood that I am constructing and expressing a personal narrative, one that will continue to unfold throughout the thesis process. I found myself constantly questioning whether I thought about a certain topic, or was it actually being stated, thus it is important that I made the foregoing biases and assumptions known ahead of time.

\section{RESEARCH QUESTIONS}

The research questions that guided this study are:

1) What were their life experiences of $9 / 11$ ?

2) Was their religious status affected by the event?

3) What is being communicated about $9 / 11$ after 10 years?

This study provided me with a unique opportunity to visit my hometown again and ask questions of my church friends as they described and explained the event, and its importance to their lives. The next chapter provides the review of literature, while the 
third chapter explains the methodology of the study. The fourth chapter highlights the findings of the study, while the last chapter provides my interpretations of the findings and links from previous research, as well as recommendations for future research. 


\title{
CHAPTER II
}

\section{LITERATURE REVIEW}

\section{INTRODUCTION}

\begin{abstract}
That is why they called it the world trade center. Among the Americans were blacks, whites, Latinos, Asians, Christians, Muslims, and Jews — as diverse in death as we are in life." (Bond, 2002)
\end{abstract}

It was ten years ago this past September that 19 al-Qaeda terrorists took control of four commercial passenger jet airliners and flew three of them into three buildings in an act of terrorism: two in downtown Manhattan and the third one near Washington D.C. The hijackers intentionally crashed two of the planes into the World Trade Center (WTC) buildings in New York City. Both WTC towers would collapse within two hours of the impact, destroying nearby buildings and killing thousands of residents and workers. The third plane crashed into the Pentagon, just outside Washington D.C., killing more than one hundred personnel working in the Pentagon, as well as all of the passengers on board (http://www.encyclopedia.com/topic/9-11.aspx). A fourth plane crashed in a field near Shanksville, Pennsylvania after passengers and crew members battled the hijackers for control of the plane. Thirty eight passengers, a flight crew of five flight attendants, and two pilots died (http://911 review.com/attack/flights/f93.html). On September 11, 2001, everyone in the United States was exposed to an incident that was unprecedented in scope and traumatic impact (Silver et al, 2002).

The September 11th, 2001 attacks were the most deadly international terrorist attack in history and the largest attack on U.S. soil since the attack on Pearl Harbor on 
December 7, 1941. Although most people did not experience a direct threat during 9/11, the attacks of 9/11, now a decade ago, have had a global effect.

(http://www.encyclopedia.com/topic/9-11.aspx). More than 3,000 people died that tragic day and although most were U.S residents, there were people from more than 50 other countries lost in the event. Specifically looking at the Korean American population, a total of 9 Koreans were victims of the attack on the World Trade Center (NYC Victims).

According to the New York Times, the United States Census in 2000 indicated an unprecedented diversity in the country. Foday Asian Americans belong to the fastest growing ethnic minority group in the United States. In percentage, they are increasing more rapidly than Hispanics" (Takaki, 2000, p, 118). Korean-Americans made up a large part of the Asian American community in the U.S., with a total of $0.4 \%$ of the total U.S. population or 1,076,876 people identifying themselves as Korean-American, according to Census 2000 data (U.S Bureau of the Census, 2001). The state specific results revealed that in 2000, there were 119,846 people that identified themselves as Korean in New York.

Thus, 9/11 affected not only Americans of varying backgrounds, but people from other countries and various religious backgrounds. The term $9 / 11$, which is mentioned throughout the thesis, refers to September $11^{\text {th }}, 2001$. When referring to the event, it has become a common accepted language form to shorten it to ${ }^{9} 9 / 1$. $^{\text {' }}$

Religion

Before a discussion begins on religion and identity, either in general or with direct reference to $9 / 11$, it is useful to open with several definitions of religion. Merriam 
Webster provides a broad definition. Religion is a set of cultural systems that have many traditions and is intended to give meaning to life or to explain the universe. Directly tied in with religion is a person's faith which is defined as belief and trust in and loyalty to God: something that is believed especially with strong conviction" (www.merriamwebster.com/dictionary/faith). Faith deals with the belief and trust in God or the teachings of religion. A second definition states that religion is $\rightarrow$ set of beliefs concerning the cause, nature, and purpose of the universe, especially when considered as the creation of a superhuman agency or agencies, usually involving devotional and ritual observances, and often containing a moral code governing the conduct of human affairs" (www.dictionary.reference.com/browse/religion).

Thus, religion is comprised of several interconnecting concepts of attitudes, beliefs, and behaviors. In this study, the religion of Christianity is examined. Today's Christianity includes a wide variety of forms, attitudes, beliefs, and practices but all center around faith in Jesus Christ (www.religionfacts.com/christianity). Attitude is defined in social psychology as a predisposition to classify objects and events and to react to them with some degree of evaluative consistency. While attitudes logically are hypothetical, they are manifested in conscious experience, verbal reports, gross behavior, and psychological symptoms" (Britannia, p. 687). Belief is defined as -Mental acceptance of a proposition, statement, or fact, as true, on the ground of authority or evidence; assent of the mind to a statement, or to the truth of a fact beyond observation, on the testimony of another, or to a fact or truth on the evidence of consciousness". (ww.oed.com) Religious behaviors can be seen as practices, such as praying, attending 
church, and so on. Now that religion is defined, the next section will discuss the changes in religion after 9/11, followed by several studies investigating these changes in America.

\section{Religion and $9 / 11$}

Mark Juergensmeyer (2004), a professor of sociology and religious studies and the director of global and international studies at the University of California, wrote an essay titled, Thinking about Religion after September 11. In the essay, Juergensmeyer explains how, after the event of 9/11, there were changes for the American population in the ways we view religion. These changes included the awareness of how religion has a dark side' and greater attention towards Islam.

He begins his essay by stressing the fact that acts of violence or terror in relationship to religion is nothing new in society. This kind of bellicose saber-rattling is not characteristic of Christianity, Islam, or any other religion, we wanted to say. In a sense we were trying to assure the public that religion has not essentially changed" (Mark Juergensmeyer, 2004, p. 223). He emphasizes that acts of violence and terrorism in direct relation to religious beliefs and attitudes have been occurring throughout the world for generations, but it took the magnitude of $9 / 11$ to bring this type of awareness to most Americans. He explains how the American public began to look at religion differently after $9 / 11$, as both a support for both sides of a global war, as well as a source of peace. It is fair to say that after September 11 all religion began to be viewed with a more jaundiced eye, as something that could inspire vengeance and viciousness as well as comfort and peace" (Juergensmeyer, 2004, p. 221). 
When 9/11 occurred, it not only tested people's religious beliefs, but at the same time questioned others, specifically Islam. -September 11 forced most of us to learn a lot more about Islam than we already knew" (Juergensmeyer, 2004, p. 223). Healey (2005) further notes that the terrorist group was identified as militant Islamic and how this particular religious group has since dominated scholarly and popular discussions.

Corpis \& Scharfman (2007) further notes:

In the past six years, a somewhat muted but nonetheless important discourse has emerged around conversion, especially Christianity and Islam. This discourse has arisen within the interstices of the more pronounced public representations of Islam in the United States, which have either demonized Islam altogether, argued that it was -hijacked" and corrupted by terrorists with aims political rather than religious, or viewed Islam and Christianity as monolithic and competing civilizations headed towards an inevitable cultural and geopolitical clash (p.1).

9/11 seems to have created a paradigm shift for Americans view on religion and its correlation to acts of terror. If anything, September 11 should have taught us that often what appears to be a religious act occurs within social and political contexts in which this act may be seen as a religious response to social-political problems" (Juergensmeyer, 2004, p. 234).

Some studies seemed to reflect that the terrorist attacks had a ripple effect, not just in New York City, but throughout the nation. The church was where people went to find comfort and social support. It was a social location where Americans gathered to mourn the deaths of thousands, to pray for the safety of the country (Hitchcock, 2002), and to cope (Schuster et al, 2001). Since the tragic events of 9/11, studies have been conducted to investigate the lingering effect on people 's religious beliefs and practices in the U.S. 
The Barna Research Group is an independent marketing research group that has been studying U.S. cultural trends related to values, beliefs, attitudes, and behaviors since 1984 (http://www.barna.org/about). In late July through mid-August, just prior to September $11^{\text {th }}, 2001$, the research group conducted nationwide telephone interviews to investigate people's religious faith. According to the online article, (2001), a total of 1001 randomly sampled adults took part in the pre-attack research. A second round was completed with a new randomly sampled group in late October and early November after 9/11, asking the same questions about Americans faith as the earlier study. A total of 1010 adults took part in second round by telephone interviews. (Barna.org)

The collected data from both time periods were compared and contrasted and the research group concluded that little had been altered by the terrorist attacks and subsequent war efforts. While changes may have been expected in people's beliefs due to the event, the results reflected that little had changed or been altered by the terrorist attacks. Although there was an increase in church attendance nationwide by perhaps $25 \%$ immediately after the attack, attendance one month later was back to - normal levels" (Barna.org). Church volunteerism and prayer was also back to preattack levels. The survey also evaluated people`s general faith commitment. Regardless of religious practices and church affiliation, the research group found no change in all the percentage of adults who identified themselves as born again Christians' and evangelical Christians'. (Barna.org)

The director (The Barna Group) stated the following: 
After the attack, millions of nominally churched or generally irreligious Americans were desperately seeking something that would restore stability and a sense of meaning to life. Fortunately, many of them turned to the church. Unfortunately, few of them experienced anything that was sufficiently life-changing to capture their attention and their allegiance... Our assessment is that churches succeeded at putting on a friendly face but failed at motivating the vast majority of spiritual explorers to connect with Christ in a more intimate or intense manner (the Barna group).

A second research study that investigated post 9/11 attitudes of Americans was conducted by the Pew Research Center. Very similar to the methodology of the Barna Group study, the Pew Research Center conducted telephone interviews nationwide with a total random sample of 1,500 adults. The study, under the direction of Princeton Survey Research Associates in collaboration with the Pew Forum on Religion and Public Life, was conducted from November 13-19, 2001, two months after the tragic event.

The Pew Research Center concluded from their study that there was general agreement among all religious and demographic groups studied that religion occupies a more important place in American life. (Pew Research Center, 2001) Yet despite this general agreement' across the board, it was not matched by an increase in church attendance, religious services, and there was not much evidence that religion was playing a larger role in Americans ' personal lives two months following the September $11^{\text {th }}$ attacks. (Pew Research Center)

Another large study conducted post 9/11 was by the Gallup organization. This group conducts and gathers data-driven news' about the world. In an attempt to find out about people‘s religiosity, telephone interviews with a randomly selected national sample of 1,019 adults, was conducted from Dec. 14-16, 2001. Frank Newport, a researcher for 
this group, concluded after analysis of the interviews, We don't find any indication in our regular Gallup poll measures of a significant change in religious behavior since Sept.11.” (Gallup, p 1). Similar to the Barna Group's findings, the Gallup organization also recorded the brief increase in religious activities and church attendance immediately after the event. They concluded however, that the self-reported importance of religion to Americans was no different 3 months post 9/11 then it was pre-9/11.

Five years following the 9/11 attacks, Steve Levin from the Pittsburgh PostGazette, wrote an article about American life post-9/11. Levin begins his article stating the obvious changes in America; the increase in airport security, secret wiretapping, tighter scrutiny of foreigners, and the higher cost of doing business. Based on studies conducted by the Gallup poll a year after 9/11 and a survey in Scripps-Howard/Ohio University poll, Levin states Five years since the day that forever will be known simply as $9 / 11$, life, in fact, remains very much the same. Church attendance, volunteering, blood donations — none changed appreciably in the past five years, despite the initial spike in numbers common following disasters" (Levin, post-gazette).

The foregoing literature highlights the impacts of 9/11 nationwide, as related to religious beliefs and practices in the U.S. Using random telephone interviews, the Barna, Gallup, and Pew research groups conducted their studies on a large scale across the nation, and found very similar results and came to a general conclusion that although there was an increase in church attendance and in attitudes/beliefs throughout the nation immediately post 9/11, it did not remain that way for long. Levin's article further details the increase in church attendance and altruism was short lived. The authors collectively 
agree that people appeared to turn to their faith in times of despair and tragedy, but as time went by, their religious commitment and beliefs gradually returned to the way it was pre-9/11.

Several smaller studies were conducted post 9/11 on stress and coping that directly relate to the research topic. The first study by Thomas Plante and Erika Canchola, (2004) evaluated the stress and coping of west coast college students regarding the terrorist attacks on 9/11. The participants included 97 students from a west coast catholic university. Questionnaire responses were administered to the group of students 8 weeks after 9/11. The study utilized four different types of scales to analysis the data. Measures included the Santa Clara Strength of religious Faith questionnaire, the Marlowe-Crowne social desirability scale, the symptom check list-90 revised, and the impact of event scale, a 10-point stress, coping, and importance of faith scale (p. 269). Results of the questionnaire indicated a moderate level of stress for the participants. While most previous research that examined the relationship between major life stresses and religious faith has found that a strong religious faith is positively correlated with coping well, this particular study showed the opposite. The researchers mentioned this may be due to a high threshold that is needed before religious coping is activated and that proximity may have been a factor; West Coast vs. New York City (p. 276).

The second study was conducted by Amy Ai, Terrence Tice, Christopher Peterson, and Bu Huang (2005). This was a study on religion and positive attitudes in coping with $9 / 11$ three months following the attack. The study surveyed 453 graduate and undergraduate students who were enrolled in mental health classes at the Universities of 
Nevada, Pennsylvania, and Washington. Data were collected by the use of a questionnaire survey at the three different schools between fall 2001 and winter 2002 terms. The results showed that the participants, who believed in a god, or spiritual entity of some sort, used various types of prayer and religious rituals for coping. Seventy five percent of the participants believed that private prayer was important in their lives. With the difficulties and stress around the attacks, over sixty two percent of the participants indicated that they used private prayer to cope with $9 / 11$ (Ai et al, 2005).

Within days of the attack, Marl Schuster, et al, (2001) conducted a national survey about parents immediate reactions to the attacks and their perceptions of their children's reactions. Using random-digit dialing, a representative sample of 560 U.S. adults was surveyed. The results found that $44 \%$ of adults reported at least one symptom of stress and $35 \%$ of the children had one or more stress symptoms. The study found that turning to religion (prayer or spiritual feelings) for both sexes, was the second most common way of coping (90\%), after talking with others (98\%) (Schuster et al., 2001).

\section{Cultural Identity}

Communication scholars have long recognized the importance of identity in intercultural research (Collier \& Thomas, 1988; Lustig \& Koester, 2000).The concepts of identity and communication, both complex issues in and of themselves, are inter-related and dependent upon each other (Collier, $1997 \&$ Shepherd, 2001). According to Martin and Nakayama (1997) the self does not create identities alone, but rather they are cocreated through communication with others. Identity is formed when individuals align themselves with particular social structures associated with race or ethnicity and then the 
idea of who they are to others is communicated. Cultural identity is defined by TingToomey et al., the extent to which individuals hold their larger culture to be important" (2000, p. 13). According to Collier \& Thomas (1988), cultural identities differ in several dimensions. These are scope, salience, and intensity. Scope refers to range of one ${ }^{6} \mathrm{~s}$ cultural identity while salience is the degree of importance of an identity within a particular communication setting. Finally, intensity refers to the relative strength a person's identity is communicated.

Ethnic identity is - \$et of ideas about one's own ethic group membership, including self-identification and knowledge about ethnic culture (traditions, customs, values, and behaviors), and feelings about belonging to a particular group" (Martin \& Nakayama, 1997, p. 74). Ethnic identity is positioned around specific sets of cultural forms and symbols, and therefore communicates uniqueness and solidarity to the outside world (Lie, 2003; Martin, 1997).

Collier (1997) argues that ethnic identities are constantly changing, being negotiated, reinforced, and challenged through communication. She explains how there are certain -properties" of ethnic identity, which are enacted and developed through communication. Identities are enacted in interpersonal contexts through avowal or ascription processes. Avowal is how a person portrays themselves (i.e., saying, this is who I am"), whereas ascription is defined as a process by which other people attribute certain identities to an individual (i.e., through stereotypes). It is through the process of avowal and ascription that identity is shaped and defined by our own and by others ${ }^{\text {‘ }}$ communicated views of us. 
Due to the fact that identity is continually being renegotiated and is dynamic (Collier, 1997; Martin, 1997), a particular community`s language or discourse, specifically in reference to their identity, is a crucial component of identity (Hecht et al., 2003, p. 57). Communication scholars, then, research and study meaningful forms and symbols within a culture (i.e., forms of communication) as a way to better understand a certain group. Obviously, identity development does not occur in the same way in every given society (Collier, 1997). The concept of identity in most eastern collectivistic countries, such as Japan, India, and South Korea, emphasizes the integration of familial and the spiritual self, rather than the individualized self.

\section{Second Generation Korean-American}

For the purpose of this study I specifically focused on second generation KoreanAmericans, the group who participated in my study. According to McGrath (2002) Understanding the relationship between ethnic identity and communication is critical to understanding the life experiences of second generation Korean-Americans" (3). To understand communication and ethnic identity among Korean-Americans, there must be an understanding of how this group came to be.

Second generation Korean-Americans, in the Korean-American cultural context, are Koreans who were born in the U.S. to parents who emigrated from Korea to the U.S. Any research intending to discuss Korean culture and identity cannot do so without acknowledging the influence of Confucianism and Buddhism. These particular worldviews or philosophies influence every facet of life in Korean culture (McGrath, 2002). Korean Neo-Confucianism emphasizes social ethics and the value of family. One 
of the main tenets this philosophy stresses the maintenance of social harmony through strict relationship hierarchy and deference to authority. It is important to be aware of the Korean Neo-Confucianism as it not only impacts first generation immigrants (parents), but also the second generation. It serves as a relevant social factor when attempting to understand second generation Korean-Americans and their religious history. Buddhism is one of the primary religions in Korean culture and according to Heerak Kim (2008), many Koreans abandoned Buddhism when they immigrated to the USA. They saw their immigration as immigrating to Christianity. Kim argues that although many KoreanAmerican parents may have not actively converted to Christianity, as immigrants to a new country who left South Korea and Korean Buddhism behind, they were willing to attend a Christian church and subscribe to the Christianity of America. Korean American churches function as Korean-American cultural centers which made the transition easy for many Korean Americans to convert' to Christianity in the context of the KoreanAmerican immigrant life and the Korea American church. (Kim, p. 15).

Sang Ahn (2000) writes what it means to be a second-generation KoreanAmerican, but also about the relationship between first generation _Korean immigrants and second generation Korean-Americans. Ahn examines the nature of second generation Korean-American ethnicity from previous studies by Myoung-Hye Kim (1992) and Soyoung Zeon (1994). Ahn explains ethnic identity within the American society and the expectations that everyone should have an ethnic identity, while at the same time, an American identity. She argues $\mathrm{It}$ is the American context in which Korean-American ethnic identity is configured. Having a Korean-American ethnic identity is part of being American because being American denotes having a positive political attitude, and 
having a symbolic ethnicity" (17). She concludes that although second-generation Korean-Americans are different from the first generation, they retrieve the alleged culture of their ancestry and at the same time recreate their own ethnicity.

For second generation Korean-Americans, a large part of their ethnic identity comes from their religious background. Kelly Chong (1998) argues how the church plays a significant role for second generation Korean-Americans in instilling and reinforcing ethnic identity. She states the ethnic church serves -as an institutional vehicle for cultural reproduction and socialization of the second generation into Korean culture" (p. 262).

Sharon Kim (2010) investigated the development of second generation KoreanAmerican Christian churches in Los Angeles and addresses the growing number of churches being created in the area. Over 56 new churches have been established in Los Angeles since 1992. -Second generation Korean-Americans, with an unparalleled entrepreneurial favor, are developing new churches that aim to shape the future of American Christianity. The development of second generation Korean-American churches is a recent and rapidly growing phenomenon in major cities throughout the United States" (Kim, 2010, p. 98). She describes a new trend in second-generation Korean-Americans churches as they are not joining mainstream churches or remaining with their parents' church. Kim finds that, instead of joining their immigrant (parent) church, they are creating their own church. They want to carve out a hybrid third space that is uniquely their own, distinct from mainstream Evangelism and from Korean Christianity” (Kim, 2010 p. 99). 
Second Generation Korean Americans and 9/11

Heerak Christian Kim (2008) wrote a book entitled Korean-American youth identity and $9 / 11$. From my research, this is the only reference that specifically discusses my topic area of 9/11 and second generation Korean-American Christianity. Although his book is not grounded in scientific research, nor is it a theoretical piece, Kim provides a great deal of information about the ethnic group investigated in this study. Heerak Kim is a Korean American Christian scholar who studies religion and has taught both in the U.S and in East Asia. According to Kim, religion is an important part of the cultural identity of Korean-Americans. The Korean-American church functions as a cultural center as well as a religious center for its members (Sharon Kim, 2010; Heerak Kim, 2008; Kelly Chong, 1998). The church is a social place where Koreans, both those born in the U.S and in South Korea, gain exposure to other Korean-Americans and learn about Korean culture. Thus, it serves as a central socializing institution preserving and teaching Korean culture and heritage as well as Christianity.

Regarding 9/11, Kim (2008) notes that for many Korean-Americans, the event brought forward questions about communal safety in America. Kim argues that for many Korean-American Christian teenagers and college students, 9/11 either pushed them away from Christianity or made their religious beliefs even stronger. He provides a historical framework of Korean immigrants and how 9/11 raised the question of safety for Koreans as an immigrant community in America. These concerns and questions came to be externalized in two completely opposite tendencies. The first tendency was active church-goers who pushed Korean churches closer toward the evangelical / fundamental 
direction in which some members became more heavily involved in church and adopted a Fundamentalist Christian approach. Thus, some became more conservative as Christians. Those in the Fundamentalist Christian communities emphasized Fundamentalist Christian rules more to ensure that the violators come into line with the rules set for the Christian community" (Kim, 2008, p 23).

The second tendency was the opposite, in that some Korean Christians left or abandoned Christianity altogether (Kim, 2008, p. 2). His rationale for Korean Americans to abandon the church was because the event of $9 / 11$ proved a false sense of religion in the minds of Korean Americans. Upon moving to America, most native Koreans, who are Buddhist, actively converted and changed their religion to Christianity because for many of these Korean American immigrants, they identified America with a Christian land. They identified the blessings of America in the areas of economy and military in terms of its Christian identity. The Korean American church with its focus on Korean cultural identity made the transition in religious identity that much smoother" (Kim, 2008, p 16).

Kim (2008) stresses that there continues to be a lack of research and study of Korean American identity (Kim, p 13). Although a few articles been written since Kim (2008), the research continues to be limited. My intention in this study was to begin to fill in the gaps about Korean Americans, particularly second generation Korean-Americans, and provide qualitative evidence and depth to the identities of those of this group who were living in New York City at the time of the 9/11 attacks. Sharon Kim (2010), Heerak Kim (2008), and Kelly Chong (1998) not only stress the importance of religion for 
second generation Korean-Americans, but also how crucial the church`s role is in shaping their ethnic and religious identities.

The foregoing literature indicates only a temporary change in religion practices immediately after $9 / 11$ in the U.S. The studies came to a general conclusion that while more people attended church services, gave more money, and prayed to cope, the increase in religious activities and altruism was only temporary post $9 / 11$. Within months after the attacks, things went back to normal' ${ }^{6}$. In reference to Korean-Americans, the authors and researchers highlighted the historical contexts of second generation KoreanAmericans pre and post 9/11, and how their identities were affected by religion, specifically Christianity. Heerak Kim mentions that Korean American Christians reacted in two ways immediately after 9/11; either they abandoned Christianity altogether or they became more religious and involved in the church. It is the lived experiences of second generation Korean Americans Christians and the impacts 9/11 had on their lives and religious beliefs that this research investigates. The next chapter highlights the methodology of this current study. 


\section{CHAPTER III}

\section{METHODOLOGY AND RESEARCH DESIGN}

\section{INTRODUCTION}

The purpose of this study was to gain an understanding of how a group of Korean American Christians living in New York City at the time of the 9/11 attacks experienced that event and whether the event had any impact on their religious beliefs. In addition, it was to investigate what they are communicating at the time of the ten year anniversary of the event. The guiding research questions were:

1) What were their life experiences of $9 / 11$ ? 2) Was their religious status affected by the event? 3) What is being communicated about 9/11 after 10 years?

This chapter consists of the 1) research design, 2) data collection steps, 3) analysis approaches to the data, and 4) issues of validity and truthfulness.

\section{RESEARCH DESIGN}

\section{Qualitative Approach}

A qualitative approach was used for this study. Qualitative research takes on a naturalistic approach to the extent that the research takes place in real-world settings and the researcher does not attempt to manipulate or change the phenomenon of interest (Patton, 2002). The purpose of qualitative research is to provide an understanding of a particular person, group, or phenomena, in natural settings. According to Krauss, (2005) qualitative research methods are best used when there is not much previously known 
about the topic, when the topic is personal, and when ones wants to know about an experience in great detail ( $\mathrm{p}, 763)$. It is used to find out the why and how of human behavior. This particular tradition within social science investigates a certain population, in their own territory, interacting with them in their own language, on their own terms (Kirk and Miller, 1986).

Based on Burrell and Morgan's (1979) typology of schools of social science research, Martin and Nakayama $(1999,2000)$ identify several distinct approaches to study culture and communication. They are: functionalist, interpretive, critical humanist, and critical structuralist. The interpretive approach is what is utilized in this study. In the late 1980 's this approach became prominent and is under the assumptions that reality is subjective, internal, and describable (Martin \& Nakayama, 1999, 2000). They argue that human behavior is voluntary and creative. The goal of the research is to describe and understand behavior.

\section{$\underline{\text { Phenomenology }}$}

The construct of this research study is that of a phenomenological qualitative design. This particular approach was first developed towards the end of the $20^{\text {th }}$ century, by the work of Edmund Husserl. Phenomenology is a rigorous process of reexamining what Husserl $(p, 192)$ termed the things themselves". The purpose of the phenomenological approach is to illuminate the specific, to identify phenomena through how they are perceived by the individuals in a situation. Phenomenology is essentially the study of lived experience or the life world" (van Manen, 1997). Phenomenological research is an introspective human science, the intent of which is to interpret and to 
understand, rather than observing, measuring, explaining, and predicting (van Manen, 1984). This method does not begin with pre-existing theories and it does not test hypotheses. Instead, phenomenology aims to describe the experience under investigation, including the significance of the lived situations and the modes of apprehension (van Manen, 1984)

According to Wertz (2005), when presenting phenomenological research, its value is established by honoring concrete individual instances and demonstrating some fidelity to the phenomenon (to the things themselves'). Research reports may, for example, contain raw data such as participants' quotations providing an opportunity for readers to judge the soundness of the researcher's analysis. According to Husserl (1962) personal experience is the material which begins the study. The investigators personal experience, beliefs, and assumptions are bracketed in order to study the realities of the natural world. Osborne (1994) explain bracketing as identifying one`s presuppositions about the nature of the phenomena and then attempting to put them aside to see the phenomena as it really is. By becoming aware and putting aside one's biases and assumptions, the researcher can engage the experience without preconceived notions about what will be found in the investigation. This awareness is seen as a protection from imposing the assumptions or biases of the researcher on the study" (Laverty, 2003).

Lincoln and Guba (1985) described questions of ontology, epistemology, axiology, and methodology as essential components in critiquing and conducting qualitative research. Ontologically, the researcher acknowledges that there are multiple truths ${ }^{6}$ and strives to understand people's motivations and actions. In the early stages of 
the proposal, I recorded my biases, expectations, and assumptions in order to begin to account for my position in relation to the group I would be studying, as well as the incident of 9/11. This effort is an attempt to not let my biases interfere with the informants expression of their lived experiences, and to enhance my ability to hear them. (See chapter 1, p. 5)

Epistemologically, this specific approach is based in a paradigm of personal knowledge. According to Van Manen, $(1984,1990)$ this research method is dedicated to describing the structures of experience as presented to consciousness without recourse to theories, deductions, or assumptions from other disciplines. We can know and study subjective reality as it is constructed, mediated and biased. Axiologically, the value in this type of research is that all participants are equal authorities and all perspectives are represented. No one particular respondent holds more or less value than another respondent. Each individual has their own story to tell and the primary aim is to understand and reconstruct experiences.

Polkinghorne (1983) supported Husserl's use of the term methodology rather than method to describe the use of phenomenological traditions. A methodology is a creative approach to understanding, using whatever approaches are responsive to particular questions and subject matter" (Laverty, 2003). The process is more often than not cyclical rather than linear.

The quality of any phenomenological study can be judged in its relative power to draw the reader into the researcher's discoveries, allowing the reader to see the worlds of 
others in new and deeper ways. Polkinghorne (1983) offers four qualities to help the reader evaluate the power and trustworthiness of phenomenological accounts: vividness, accuracy, richness and elegance. Is the research vivid in the sense that it generates a sense of reality and draws the reader in? Are readers able to recognize the phenomenon from their own experience or from imagining the situation vicariously? In terms of richness, can readers enter the account emotionally? Finally, has the phenomenon been described in a graceful, clear, poignant way? Lincoln and Guba (1985) described the goal of credibility in phenomenology research as demonstrating that the inquiry was conducted in a manner to ensure the topic was accurately identified and described.

\section{DATA COLLECTION}

\section{$\underline{\text { Interviews }}$}

The interview process in the phenomenological tradition works within an environment of safety and trust, which needs to be established as the outset and maintained throughout the thesis process (Laverty, 2003). Semi-structured interviews were conducted for this study and the specific questions were generally open in nature. Interviews were chosen to understand the individual's point of view through the description of their own lived experiences (Luborsky, 1994). Informants were selected because of who they are and what they know, rather than by chance. An interview guide was created consisting of open ended questions. (See Appendix B) This was designed to give room for the participants to answer freely and base their responses on their lived experiences. As a researcher, I made a conscious effort to probe and back track throughout the interview process. By probing answers, I wanted to provide further clarity 
on specific points. All respondents were asked the same questions in the same order of the interview guide. This is meant to increase comparability of responses and make the analytical process easier to track as well as avoid order effect issues.

According to Hycner (1999) the phenomenon dictates the method (not viceversa) including even the type of participants. For this study I chose purposive sampling, considered by Welman and Kruger (1999) as the most important kind of non-probability sampling to identify the primary participants. I selected the sample based on my judgment and the purpose of the research. As I was a part of MBS church for many years, I looked for those that have had experiences relating to the phenomenon to be researched" (Kruger, p 150). Participants also had to be living in New York City at the time of the 9/11 attacks. I made use of social networking, through the internet to connect with church members. Interviews were arranged prior to my departure to New York City.

In order to trace additional participants or informants, I used snowball sampling. Snowballing is a method in which an informant or participant is asked to recommend others for interviewing. (Babbie, 1995). Once a recommendation was made, I asked if was possible to get his or her contact information. The snowball sampling technique enabled me to get three informants.

I conducted a total of eight face-to-face interviews with individuals who lived in New York City at the time of 9/11 and with whom I attended church prior to 9/11. A total of seven interviews were conducted while in New York City. The only one that took place in Oregon was the pilot study. In qualitative research, there is a concept of tess is 
more", which entails the importance of working in a smaller group, for a longer period of time. The purpose of the qualitative interview is not to discover how many, and what kinds of people share a certain characteristic. It is to gain access to the cultural categories and assumptions according to which one culture construes the world." (McCracken, 1988, p 17)

With the total of eight interviews conducted, the average interview time was one hour and ten minutes. A total of nine hours of interview time was recorded and transcribed. As a visitor in New York City, initially I was not clear where the seven interviews scheduled there would take place. The interviews took place in several locations, all of which were chosen by the interview participants. Three interviews took place in dining rooms of individual's homes in Staten Island. Five interviews took place at either an office room at the headquarters of 180 Church in Staten Island, New York, or in a gymnasium room, that the 180 Church rents for youth service every Sunday evening, which is also located near the Staten Island mall. A pilot interview was conducted in Portland, Oregon and another interview was conducted in Fort Lee, New Jersey. All but one interview was conducted in a quiet setting. The tape recorder was able to pick up all the audio of the interview, including background noise.

The demographics of the informants for this study were unique and had to fit certain criteria. First, participants had to be a second generation Korean-American, that is any person who was born in the U.S., but his or her parents were from South Korea. The second criteria were that the informants must have been present in New York City at the 
time of 9/11. Third, the informants also must have attended MBS church for at least five years prior to $9 / 11$.

\section{Protection of Human Participants}

Before interviews took place, approval from the Human Subjects Research Review Committee at Portland State University was needed to conduct the study. Once I received permission by the university, I then proceeded with the study. Each participant signed the informed consent form (See appendix A) and was audio recorded.

To ensure the interview process did not harm the interviewee in any physical or emotional way about $9 / 11$, a corresponding information sheet of available social services in New York City was given to interviewees to the close of each interview. (See Appendix C) All transcriptions and informed consent forms are key-locked protected, only to be reopened for future analyses or research. Given that technology may fail and data may be lost, as cautioned by Easton, McComish \& Greenburg (2000), I keep a separate USB drive of all the recorded interviews and a separate binder of all the transcripts in a locked cabinet drawer.

\section{Pilot study}

A pilot interview was conducted in Portland, Oregon with a former member of the MBS church prior to leaving for New York City. The informant was also selected because he had been a member of MBS church for more than five years, was in New York City at 9/11 and is Korean American. Conducting a pilot interview served many different purposes for the research. It allowed me to test the questions in the interview 
guide and later be able to adjust the questions. The pilot interview also allowed me to add new questions to the interview guide, therefore strengthening the interview guide and process. The demographic profile, collection process, and data gathered were considered sufficiently coherent with the rest of the sample to be included in the final study.

\section{Transcriptions}

Each interview was recorded on my laptop using a program called Audacity. It is a program that can record anything from a laptop, save the interviews in files, and be played over again in a slower time frame. Being able to hear the interviews during the transcribing process, made it easier to replay crucial statements and quotes. Any breaks or pauses during the interview are indicated with three periods (...). Nonverbal cues noted were written on the researcher's interview guide.

To protect their identity, each interview participant was identified by a pseudonym. Each interview was transcribed verbatim by the researcher and typed onto Microsoft Word documents that included the date, start and end time, place, and pseudonym of interviewee. Quotations have been edited to enhance confidentiality.

Two identical binders were created containing all eight transcribed interviews. The first was used to cut and paste different themes and patterns. Using the binder to place different quotes and ideas together made the clustering of units more easily assessable. The second binder was used as a hard back up copy in case something happened to the original working copy. This second copy is located in a key-locked cabinet, with the USB drive of the recorded interviews. 
Field notes were used as a secondary data storage method in this study. Because of human error and not being able to remember every bit of detail from interviews, I also relied on field notes to retain data gathered. Lofland \& Lofland (1999) explain how crucial field notes are in a phenomenological study. This implies that the researcher must be disciplined to record, subsequent to each interview, as comprehensively as possible, without judgmental evaluation. Four types of field notes were made:

- Observational notes $(\mathrm{ON})$-_ what happened notes` deemed important to the researcher.

- Theoretical notes (TN)- attempts to derive some kind of meaning.

- Methodological notes (MN)- key reminders or critiques to oneself on the process

- Analytical memos (AM)- general summaries of the interviews or progress reviews.

\section{EXPLICITATION OF THE DATA}

The heading data analysis` is avoided on purpose because as Hycner (1999) cautions, the term analysis“ has a dangerous connotations for phenomenology. The term analysis“ which usually refers to breaking into parts" can often mean a loss of the whole phenomenon, whereas explicitation' implies an investigation of the constituents of a phenomenon, while keeping the context of the whole (Hycner, p 161). Keeping in mind the study is investigating a phenomenon, I used Hycner's (1999) five step explicitation process to the data. The five steps are:

1. Bracketing and phenomenological reduction. 
2. Delineating units of meaning.

3. Clustering of units of meaning to form themes.

4. Summarizing each interview, validating it and where necessary modifying it.

5. Extracting general and unique themes from all the interviews and making a composite summary.

Bracketing is the first step/stage of interpreting the study's data. Derived from phenomenologist Edmund Husserl, bracketing is intended to suspend judgments about the natural world that precedes phenomenological analysis. I acknowledge my own presuppositions and biases. (See Chapter 1) It is a deliberate and purposeful method so that my personal views or preconceptions do not enter the unique world of the informants (Creswell, 1998; Moustakas, 1994). It opens the researcher to the phenomenon -in its own right with its own meaning" (Hycner, 1990). Bracketing further suggests that —. in a sense that in its regard no position is taken either for or against”. (Lauer, 1958, p 49).

Qualitative scholars not only see themselves as observing the meaning behind communication, but also see themselves as actually being part of the process of meaning making (Krauss, p 763). As a researcher with an interpretivist mindset, I understand how 9/11 impacted my religious outlook and not everyone may have had the same outcome as I did. In this paradigm, I understand that no single truth exists and there are multiple truths and multiple realities to examine. It was crucial throughout the process of the study to acknowledge (bracket) my own biases and past experiences, and not let them affect the findings of the study. 
I revealed to each informant how 9/11 impacted my life, specifically religious beliefs, after the interviews were completed. I did not want the informants to think about my story before and during the interviewing process. This could have affected their answers, based upon my experiences. I began and finished each interview with the goal to hear about the informants ' point of view and ensure that my personal story did not impact the informants during the interviews in any way.

The second stage of explicating the data is delineating units of meaning. In this stage, statements that are seen in the transcripts that illuminate the researched phenomenon are extracted or issolated“ (Crewswell, 1998 ; Hycner, 1999). I first approached the interview transcripts using both a vertical and horizontal reading, as suggested by Lincoln and Guba (1985). A vertical read is when the researcher first reads through each interview transcripts separately, drawing out units of meaning from each interview. This is where I initially made substantial judgment calls, while still bracketing my own presuppositions, in order to avoid wrongful subjective judgments (Groenowald, 2004). The list of units that had relevant meaning was extracted from each interview transcripts and was carefully scrutinized. To do this, I considered the literal context, the number of times a meaning was mentioned, and also how it was stated, whether it be non-verbal or through para-linguistic cues (Hycner, 1999).

The third stage in making meaning of the data is clustering of units of meaning into themes within each transcript. With the units of meaning in hand, I rigorously examined the list of units to highlight the essence of meaning of units within the holistic context of the study. Clusters of themes are usually formed by grouping units of meaning together 
(Creswell, 1998; King, 1994; Moustakas, 1994). Hycner stated (1999) Particularly in this step is the phenomenological researcher engaged in something which cannot be precisely delineated, for here he is involved in that ineffable thing known as creative insight" ( $\mathrm{p}, 150-151)$. While reading the various interviews, I had to consciously remind myself not to take-for-granted certain statements or topics. An example of this is when informants spoke about their memories of the distinct smell in the air due to the burning buildings. I experienced the smell of the burning buildings myself which was a factor in my experience with the event. Just because I had a similar experience of the burning smell, does not mean I should neglect and not describe the informants experience as well. According to Hycner (1999) there is often an overlap in the clusters, which is to be expected, given that the study is focusing on human phenomena. By investigating the meaning of the various clusters, central themes are determined, which expresses the essence of these clusters" (p, 153).

The fourth stage to making sense of the data is by summarizing each interview, which incorporates all the themes highlighted from the data, which intends to give a holistic context. By summarizing each interview, it allowed me to better understand how the phenomena of 9/11 affected each individual and in what specific ways. Hycner (1999) states, Whatever the method used for a phenomenological analysis, the aim of the investigator is the reconstruction of the inner world or experience of the subject. Each individual has his own way of experiencing temporality, spatiality, materiality, but each of these coordinates must be understood in relation to the others and to the total inner $={ }_{\text {world' }}(\mathrm{p}, 153-154)$. 
The final stage of the explication of the data is extracting general and unique themes from all the interviews and making a composite summary. So after the vertical read of each transcript, I completed a horizontal read across all interviews looking for connections of meaning units among the interviews. This process of searching for themes across interviews is the fifth and final stage of the process.

Once the process from stage 1 through 4 is completed, the researcher has to carefully section off the general to unique themes derived from the interviews. It is important not to leave aside the unique or minority voices. They need to be heard so that the counterpoints are highlighted regarding the phenomenon researched. The researcher concludes the explication by writing a composite summary (step 5), which is intended to reflect the context from which the themes emerged (Hycner, 1999 \& Moustakas, 1994). At this point the process (including writing) transforms participants ${ }^{6}$ everyday expressions into expressions appropriate to the scientific discourse supporting the research" (Sadala and Adorno 2001, p. 289).

\section{VALIDITY AND TRUTHFULNESS}

Schurink, Schurink, and Poggenpoel (1998) emphasize the truth-value of qualitative research and list a number of means to address this issue. In this study, the first was the actual phenomenological research design in this study. I bracketed myself consciously in order to understand from the informant's point of view and to have a insiderperspective“ (Mouton \& Marais, 1990). Bracketing took place in the beginning stages of the study, prior to the interviews, and prior to the transcription process. 
The second means I chose for validity was to conduct a follow-up email and telephone call to the informants two weeks after the interviews took place. This was done to ensure any questions or last minute comments were accounted for in the study. I also wanted to make sure informants did not experience any personal discomfort as this may have been a sensitive topic for some people.

The third means I employed, as previously mentioned, was conducting a pilot interview prior to my departure to New York City. The pilot study helped me to better formulate the interview guide and ensure the questions asked, made sense and were directed toward answering the research questions.

The next chapter discusses research findings based on the phenomenological design and the emergent overarching themes and patterns in the interviews. 


\section{CHAPTER IV}

\section{FINDINGS}

\section{INTRODUCTION}

The purpose of this study was to understand the life experiences of second generation Korean Americans who were in New York City at the time of the September 11th, 2001 attacks. This chapter will begin with the demographic profile of the study participants, followed by a discussion of the initial themes and patterns taken from the transcribed interviews.

\section{DEMOGRAPHIC CHARACTERISITICS}

All participants spent most of their life on or near Staten Island, New York. Although one informant was born in South Korea, each informant identifies themselves as second generation Korean-American. Out of the eight people who took part in the study, only two people currently live outside of New York City; one in New Jersey and the other in Oregon. Six informants still live in Staten Island, New York. All participants attended and were a part of Marn Baek Sung church for a minimum of five years prior to the 2001. The current age range of informants is between twenty four and twenty eight years old. The average age of the informants is twenty six years old and the median age between the ages of twenty five to twenty six. Thus in 2001, the informants averaged in age from fourteen to eighteen years. There were a total of three females and five males in the sample. 
None of the informants are married or have children. With respect to living status, three participants reported living with family members, while the five others shared housing with nonfamily members. Two informants are currently in college and the others have undergraduate degrees in various disciplines. Except for the individual that works in Oregon, all the informants work in Manhattan. Three informants work for Macy`s corporation, Times Warner, and Road Runner music label. The individual currently living in Portland, Oregon, works in a financial firm. Four of the eight informants are active members and employees of 180 Church. 180 Church is an evangelical, interdenominational church that has two locations: one in Staten Island, New York and the other in downtown, Manhattan. The Staten Island location is the main headquarters of 180 Church and holds evening services aimed towards teenagers. The downtown location has services on Sunday mornings that address the adult congregation.

\section{EXPERIENCING 9/11: Initial Themes and Patterns}

As this is a phenomenology study, it was important to highlight the informants lived experiences of 9/11 and how they perceived the event then and now. Once the interviews were completed and transcribed, initial emergent themes and patterns were formulated. This section describes similarities and differences in the informants ${ }^{6}$ experience. This does not fully encompass each individual‘s experiences, but does allow readers to understand from the informant's point of view, their experiences, feelings, and opinions both during and after 9/11. 
As Lincoln and Guba (1985) state, if you want people to understand better than they otherwise might, provide them information in the form in which they usually experience it" (pg, 120). Themes and patterns were documented by means of delineating units of meaning from the interviews and clustering the units of meaning into general themes (Creswell, 1998; King, 1994; Moustakas, 1994). The themes and patterns discussed are divided into four major sections or categories that consist of subthemes. Selected quotes illustrate thematic features. It is important to separate the different categories to help the reader differentiate what was discovered throughout the interview and analytic processes. The four major categories are: I: The day of the attack. II: Post 9/11. III: Religious Impact. IV: 9/11 Ten years later.

\section{I: THE DAY OF THE ATTACK}

The first category includes topics of informants ‘ experiences during the day of 9/11. The first pattern explained is location, followed by the significance of age. Next is how the informants found out about the attacks. Fourth, their initial reactions to the attack are described followed by seeing the smoke from the burning buildings. After the informants lived experiences of 9/11 are discussed, a short internal summary is provided. After the internal summary the study transitions to the second major section which details changes for the informants“ post $9 / 11$. These changes include the days immediately following 9/11, changes of worldview, personal connection to the event, and coping. The two remaining major categories that follow the post $9 / 11$ section are religion and what is being communicated about 9/11 ten years later. 
Initials used to refer to informants in direct quotes are pseudonyms to protect their identity. The meaning of numbers in each quote refers to the page(s) number where the quote appeared in the interview transcripts.

\section{$\underline{\text { A. Location }}$}

The first pattern that emerged from the interview data was the actual location of the informants on September $11^{\text {th }}, 2001$. The location of each informant and their loved ones that day is an important factor because it physically places each informant where they were during the attacks and how it impacted their experiences throughout that tragic day.

When asked about their experiences of the day of $9 / 11$, each informant began by describing their experiences in a high school setting. BK +remember I was in Staten Island at the time. I was at State Island Tech. Yeah, I think most of us were in either second or third period around that time. The first time I remember anything happening was at gym time" (3). EC I was in school at the time. I think I was in assembly or something in the class...for some reason we were called to the basement" (2). GJ - ..oh, I remember this clearly...I was in earth science. I was on the top floor because earth science class was on the top floor of Wagner, when it all went down" (5).

RK was in Tottenville High School at the time. RK _..parents were coming into classrooms and grabbing their kids. My girlfriend in school told me what just happened" (1). AR stated $€$, the day of $9 / 11$ I was at my high school...I think I was in my art class" (3). CF -so basically on 9/11...I went to Petrides High School. When I was in 
school, I don't know if we were sponsored but everyone had mac books. So it was a high tech type of school. So around 10:30am, everyone in the school knew what happened" (2). NY †think I was a junior when it happened? Anyway I was in school” (1).

DJ was the only informant that went to school in downtown Manhattan and he would end up walking towards the fallen buildings from his school. DJ yeah, to start, I was in school. I attended Hunter College High School at the time. On $96^{\text {th }}$ street. I was in the city..." (3) His lived experience is unique in that he was able to walk towards the site after the collapse of the World Trade Center (WTC).

What also played a part in their experience was the location of their family members during 9/11. Although in high school themselves, several informants had loved ones traveling and/or working in downtown Manhattan during the attacks. GJ's brotherin-law was working in one of the twin tower buildings at the time. That's another crazy story. He is sort of lucky to be alive because he was running late to work that morning and he was actually stuck on the subway, on his way to work. He was stuck on Canal Street when all the public transportation shut down" (6).

RK's younger and older brothers were in the city at the time of the attacks and she was worried because she could not contact them.

Iwas just trying to figure out what was going on because at first you know, when we were going through the hallways, like, kids were just leaving out of school...once I found out what happened, I got really worried because my brother went to school right there. (Stuyvesant High School- just a few blocks east of the 
World Trade Center). I didn't know where he was at. My older brother was going home to Boston and he was in the city taking a bus, so I didn't know where he was at so...that was my worries more or less...my parents were in New Jersey, so I didn't worry about them at the time. Nothing in Jersey to harm! (laughs)" (3).

NY talked about how he worried about his parents and family friends in downtown Manhattan during 9/11. It was a crazy day. I couldn't get in contact with my parents for a few hours. I just knew when I started hearing the news of what was going on, I immediately started to panic and wonder if my parents and friends got out safely. They were really close to the buildings at the time and I had a few friends that went to school around the area!" (14-15).

\section{B. Age Factor}

A common pattern throughout the interviews was informants mentioning their age and how they thought age affected their perceptions and experiences of $9 / 11$. As BK reflected + mean I was very naïve what I was 15 years old and I mean you ARE naïve when you are 15" (11). (caps indicting added emphasis)

EC remarked Because I was 15 at the time, I wasn't up to date on politics, the government, to what was going on overseas. When 9/11 happened, I didn't know what to think...I just remember being so confused. I was a kid in a big place. Things were hectic and my parents were really worried...(6) We (the church members) were so young, I think I was 15 . At the time I was worried about school and my social life. SAT's was a huge concern that year, not what was going on with the world trade center. So I think my age diluted my interest" (8). 
GJ mentions age several times throughout the interview. +think at that age, I don't think it's something so extreme. I guess it didn't really affect me at that

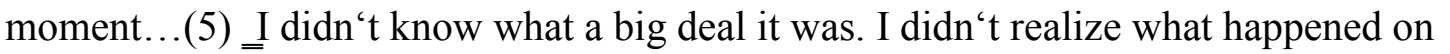
such a large scale. I think my immaturity had to do with it. We were 15 at the time? We $\operatorname{didn}^{`} \mathrm{t}$ witness a terrorist attack before and it was new to us (8). She goes to say $\Psi$ think it was our age that made a difference and not realizing how big this attack was...like the magnitude of what happened. And in that sense, my mind was a blur, it was very confusing (11)... yeah like nothing was clear at that time or moment...and I think nothing is really that clear when you are that young you know? (laughs) Not a care in the world" (13).

AR Iwas way too young at the time. I didn't have any friends there or anyone working around there" (5).

DJ commented - . I also think I am distant from it because I was completely absorbed with personal things at the time. Personal struggle with the family so....the biggest thing for me in high school years was the brokenness in my own family. That was a completely separate story to $9 / 11 \ldots$ so it provided a weird distraction for me" (laughs). (9) He further adds well, when you have personal problems at home, those things are seemingly huge! Bigger then things in the actual world. I was having relationship problems with my dad and he wasn't really coming home at the time, so that made a difference during my high school years. Compared to $9 / 11$, my personal home problems were more important and relevant. (10)... - My life was very small you know? In terms of what it actually was. I was just a student, going to school. My goal at that time was to please my parents. So with real goals like that, who knows, the Statue of Liberty could have been bombed. Didn`t really matter. It would have just been a bombing and I 
would still be at home, thinking how to please dad...getting good grades in high school" (laughs) (14).

\section{Finding out}

An emergent theme in the interviews was how students were informed about the planes hitting the World Trade Center. Informants found out what was going on from several different sources. The first was from teachers, the second through rumors/wordof-mouth circulating around the school among the students and third was through technology.

\section{Teachers}

Several informants were told what was occurring either through the public announcement system in the high school or directly from teachers/faculty. DJ $\mathrm{Ht}$ became a reality when the teachers told us that there was umm..a real situation downtown...the school went to like...their safety mode‘. Kind of like lock-down mode. There I knew something was wrong." (3)

NY Before home room started the announcement were always made..that day... what I remember was random students running down the hall crying...we all thought that she probably just got into a fight or something like that...I just thought _oh, another fight'..next thing we knew, a teacher ran down the hall crying too! So that caught everyone's attention...then oh! The loud speaker..our principal came on and she basically told us not to freak out about it, but she announced that one of the buildings got hit and on that day of $9 / 11$, it was totally different...the principle said there were reports of a low flying plane in the city...next thing I heard, the update was a plane hitting the twin towers". (2) 
GJ -Basically the teacher got notification from the faculty that something had happened to the twin towers and umm...said that a plane crashed into it. And then kids were like _what's going on?' you know, kids were shouting out —oh m god, my mom works there!' or _my dad works in that area! Kids starting flipping out!" (4)

AR Ithink I was in my art class and I found out what happened through my teacher...It was a confusing time. Before I found out from my teacher, I found out the first reports through a classmate. He told me a plane crashed in the buildings somewhere in the city. So I thought it was like a small plane or something like that. I thought I misheard of a helicopter? A two-seater? I don't know, a bunch of questions started to come up" (4).

BK + started to take it $(9 / 11)$ more serious when the teachers started getting more concerned. Even my gym teacher and other aids were really worried and the staff was worried. So I thought that there was some weight to it' (2).

\section{Rumors}

Rumor as a source of information was an emergent pattern in several interviews including $\mathrm{AR}$ 's preceding quote. Most of the informants passed off the attacks on the WTC because nothing was verified for them by the teachers and even on the radio. As noted by some informants, some technology was not available then (2001), other technology like cell phones were not useable because the cell phone towers were down.

AR $\mathrm{hmm}$... I thought it was a rumor going around in high school. I think that's a good way to explain it... and then...once I realized this can possibly be for real, I 
just...the only emotions was pure anger...I just couldn 't believe what was happening."

RK - My girlfriend told me what happened...I think it started amongst the students...we all met inside the school and called people in the city and stuff...I was just trying to figure out what was going on because at first you know, when we were in the hallways, kids were just leaving school." (2)

Even though DJ was in school in the city during $9 / 11$, he talked about how he just waited for updates. We were just...we went about our business in school. We were all just in classrooms; waiting for the latest updates...basically um...I first remember hearing about it through a buzz, with the students in the school. There was a definitely a change in atmosphere from the school, that something happened. People were like $\rightarrow$ h, I heard a plane crashed' ... umm when I first heard it, I didn't pay much attention to it because it‘s a little surreal right? It's a little weird, so I just passed it off as rumors". (3)

GJ discussed how -At the time in school, no one really knew what was going on. We were told that a plane had crashed into the twin buildings and a second hit another building. It was more word of mouth back then. It didn't seem like such a tragic thing until things kept getting worse.” (12)

BK -The teachers kept telling us to stay calm as they tried to figure out what was going on and it wasn't until a couple minutes afterwards, I heard the PA announcement saying that..the rumors were true and the twin towers were hit...We didn't have TVs in the gym so, yeah. At first there was just a buzz about 
it. It was...it was just speculation then. It was more curiosity. Kids just talking about random things. One thing lead to another..like @oh, someone hit the twin towers' you know? (pause) A lot of people dismissed it. Some people were like _oh, it's justa false rumor going around', but then um...I started to take it a little more serious when the teachers stated to get more concerned. Even like my gym teacher and other aids were really worried and the staff was worried. So I thought that there was some weight to it. It wasn't until a couple of minutes afterwards, I heard a PA announcement saying that the rumors were true and the twin towers were hit" (3).

\section{Technology}

The presence and usage of technology in gathering information was another theme that arose from the interviews. EC - Athe time, it's crazy to think about it now, not a lot of us had cell phones and there were no TVs in the classrooms. Information was delayed and so many rumors were going around...I had no idea what was going on. Nothing was confirmed over the PA system" (2).

AR - Most of the queues were not working because of the crash. I think it was because of the reception or something like that. But yeah, it was related to the buildings itself. I remember people had trouble contacting others on their cell phones and there was a lot of static, even on TV"(4).

NY Things were totally different back then...we did have TVs but it was through VHS, no cable. So the TVs needed reception and what I recall was the TVs not working back then...so no one had a visuals of it..no one was watching it live... It was 
scary. I recall at the moment...because cell phones weren't working. You couldn't make outgoing calls. Couldn't call anybody” (4).

AR $\Psi$ think it was because of the reception or something like that. But yeah, it was related to the buildings itself. I remember people had trouble contacting others on their cell phones and a lot static even on TV. I didn't have cable at the time so the news that day was choppy" (4).

GJ At the time in school, no one really knew what was going on. We were told that a plane had crashed into the twin buildings and a second hit another building. So it was just a lot of people talking. It was on the news, but we did not have any TVs in the classrooms and people didn't have internet on their phones then. I think that is way I didn't react so much more. Because it was more word of mouth back then. It was like oh, a plane hit'. It didn't seem like such a tragic thing until things kept getting worse. It was ten years ago, but a lot has changed since then on how we get information and news....a lot of miscommunication there" (12-13).

In contrast with the foregoing excepts, $\mathrm{CF}$ had a different experience. CF - So it was a high tech school, so around 10:30 am, everyone in school knew what happened...what had happened and everything. Because we were online and in third period I was in my social studies class. Someone was like there's a plane that went through the world trade centers'. I was like _o what?' Yeah...we all started watching the news and searching online for the facts. People were calling others. It was like fanatic" (2). Because of her location, that is, the type of high school she attended, she did not have 
to rely on other students or teachers for information as the other informants reported.

Even though CF had a laptop, she mentioned all communications were out...there was no cell phone reception. The TV channels was not even working. I had to listen to the radio at times" (3).

\section{Initial experiences}

The initial experiences of 9/11 are discussed below. Informants expressed a range of emotions and thoughts during the day of 9/11. Their initial experiences are categorized into three subthemes: 9/11 described as a movie, a confusing and chaotic day, and seeing the smoke from the burning buildings.

\section{9/11 like a movie}

$\mathrm{CF}$ Ithought that it was an error or something. I thought that was a movie being filmed around there. News began to show on AOL about what was actually going on" (4).

DJ + think for me what happened was...it was sort of like watching a movie unfold. I am sort of emotionally connected with it, but I am not really living it. I knew friends that had family in that place and I was sort of in the area...” (7).

GJ It was like a movie I swear. I think the teacher got a call or the news from the intercom, but people were flipping out! Basically everyone knew! At first I didn`t think it was a big deal. Like, um, we didn`t know it was a terrorist attack you know?` (5). 
EC - Sd was listening to the news on the radio and I' $\mathrm{m}$ like that makes no sense dude. Are they shooting a new movie or something?' See, I thought it was an accident. It sounded like a movie plot. I don't know if the right word is shocked, but it was surreal...because I mean, when does this happen in life? You know? Who would do something like this? Who would want to crash into the world trade center?" (3).

\section{Confusing and Chaotic day}

A second cluster reflected a range of feelings from not believing what was being shown on television, to being shocked and paranoid, scared, worried, and angry. For several informants it was like a spiritual battle or war.

EC + remember going through the rest of the school day, seeing a lot of people in paranoia and there were some people that didn't really care" (5).

NY $-U m m$..it seemed like a normal day..so it all started out kind of strange...the whole thing brought attention to the whole classroom. It didn't make sense what was going on and people stated getting curious about what was going on. People started to wonder, next thing we know is...the buildings got hit" (1).

GJ It was a mixed bag of emotions. I was scared at the time, clueless, hopeless, and confused because again, students around me were going crazy about their situation with loved ones...so it didn't affect me during that time or at that moment in the classroom. I just remember, holy shit, you know'? Once I got home and watched the news, I really felt like shit. I did cry for those families and I did cry up to three in the 
morning. Like, what had happened to everyone else and how it deeply impacted people" (12).

RK recalls her memories of being in Tottenville High School at the time of the twin towers being struck by the airplanes. It was a confusing and chaotic day... Not that many kids were paying attention in class and we had a lot of kids being pulled out of class. Umm...it wasn't too bad because Tottenville was on the other side of Staten Island, which is the opposite end of where downtown Manhattan can be seen.” (5) She later added + was shocked...it seemed unreal. You wouldn' ${ }^{\prime}{ }^{\text {' }}$ think that something like that would happen.... and then worries and panic. You didn't know what was going to happen next" (6).

BK - They started calling on their cell phones. There was just a lot of mayhem going on... you know, a lot of worries and a lot of fears, especially because most of the parents worked in the financial district and students were literally freaking out! Some didn't know what to do and just start panicking... So they (students) were scared out of their minds. They were like um...some were constantly worried, some were crying. I was lucky to have one of my brothers come pick me up at school. It took forever! (laughs) because of traffic and buses not running...yeah, I think most of us were in school either second or third period around that time" (3).

DJ recalled + acted like nothing happened...the only thing I was thinking about honestly at the time was umm. I was active in church. I remember thinking, well this is odd' (laughs) was this a spiritual battle? I remember thinking of reflective thoughts 
because it didn't directly impact me. I was wondering if the world was coming to an end" (7).

AR -Well in school a lot of people were in shock...just didn't know what to do. Kids were just in disbelief. (5)... It was more of a shock. I couldn't believe it until I got home and listened on the radio and saw it on the news...so we were worried about friends and family. Personally for me, I remember that day...nationally, I didn't realize how much pride I had in the U.S.A. until it happened...I took a moment and actually thought about joining the army. Because I figured this is time when America was going to retaliate, so I thought it was going to be a full blown out war. So I actually thought about going to the army after I graduated high school" (6).

$\mathrm{CF}^{\text {‘s }}$ initial reaction was being scared and worried and she knew my parents store location in the city and had visited the store on several occasions.

Basically like, I wanted to make sure everyone was alright. So like, I knew your parents had the store in the city, pretty much next to the towers. I knew (mentions mutual family friend), had a store on Wall Street too. So that was my instant reaction and concern. Make sure your parents were OK...umm and at the same time, I heard bricks and debris was hitting Stuyvesant High School. I heard three students got hit around the area because of the buildings falling, so I thought —oh my gosh". I thought of (another family friend that attended Stuyvesant) She ended up walking twenty two blocks to get on the Queens railroad to get home" (5). 


\section{Seeing the smoke}

Three of the eight informants mentioned the smoke from the burning buildings. Witnessing the smoke myself that day, the smell of the burning buildings and seeing the smoke across the sky made the event more realistic and scary. This is worth noting as it provides further detail to their lived experiences and what $9 / 11$ felt like for them.

GJ Ido remember the smoke. The smoke that traveled to Staten Island...Umm. It was huge! Two buildings burning. It made me realize Staten Island is closer than I thought. I mean, the buildings were right downtown and we did live closer to that area. Yup, so one thing I noticed was the smoke outside. It was thick and black outside and scary. Like a really dark cloud... crazy scene. I can't remember if it was coming out of school or the next day, I just know there was a lot of it" (13-14).

NY added further perspective +know that New Dorp High School was close to the shore of Staten Island and you could see and smell the smoke coming from the fallen buildings. When the first plane hit, you can see that clouds going across Staten Island and when the second one hit, Staten Island just went dark...I recall sitting next to the window. I remember a student next to me, turned around and pointed towards the city. There was a small dark cloud starting to form...it was eerie to see. When the first plane hit, it wasn't to the point where the clouds were filled but I saw a little bit of black clouds...we all stared out of the classrooms. We saw everyone else running out of school. I remember a lot of students were outside waiting for the bus, but since the buses stop running, everyone was just 
crowded at the bus stops...by then the clouds from the smoke started to reach Staten Island" (3).

DJ talked about walking down to ground zero during the event. As he was the only informant in Manhattan during 9/11, he spoke about how being in the city and seeing the smoke, was a social benefit for him. Icould tell my friends,' Yo I was in the city;, so yeah, I saw the smoke. It was pretty crazy seeing smoke coming from downtown. Never did I imagine seeing fire coming out of the city...crazy... (19).

The forgoing highlights where the informants were when the Twin Towers were struck, how they learned about the attacks, their initial reactions to the event and how the factor of age impacted their perspectives of and reactions to the events. There were somewhat similar stories from all of the informants. Everyone was still in a school environment when the planes hit the World Trade Center. In response to the event they all shared similar thoughts about being confused, and it being a time of chaos. Informants reported experiencing a range of thoughts and emotions that day, affected in part by their age. Information was scarce and inaccurate. The informants were unsure what to do, and they were not clear about how to respond in a terrorist attack. They relied on the school faculty, technology, and fellow students for guidance and information. In the context of location as mentioned earlier, the smoke traveling to Staten Island was experienced by a few informants that was an added dimension of the day's events.

The following emergent themes are based on the informant's experiences in the days following 9/11. Included are what they did immediately following 9/11, their 
personal connections to the event, changes in their worldview, and how informants coped with the event.

\section{II: POST 9/11}

\section{A. Experiences immediately after $9 / 11$}

When asked about their experiences in the days after $9 / 11$, similar stories were told. Following $9 / 11$, the informant ${ }^{\star} \mathrm{s}$ memories were primarily situated in the home or at school. Some informants mentioned staying home watching television for news and updates, while others mentioned how going to school was difficult because of absent students and a lack of motivation.

NY It was tough for everybody. For people that lost their family members or...close friends or whoever in the buildings. I didn't go out much...stayed home and was watching a lot of TV...new updates was coming in...bodies being discovered every day. News of people surviving in the buildings... or like updates on who was responsible for the attacks...every day, new stories" (6).

AR +remember when I got home that day. I was glued to the TV for days. I didn't do any homework or anything, just the TV and listening to the radio...just looking at the time frame. When, how, things like that" (7).

EC - Đays after the event...I think there was no school at the time. I remember my parents trying to drop me off at school and my parents were told by the school faculty to take (students) them back home. The school said if the kids could not stay home of 
working parents, then the school would watch the kids. So at Wagner, there were no actual classes for several days. (9) A good amount of high school kids didn't come out to school. Some kids didn't come for a month later. Some kids took it really harsh. Just notice that some people were not there as often as they should be" (12).

DJ There were actually a few students in school that lost their parents that day. In those moments, I did the whole notion of trying to be there, being encouraging for my friends. You know, be there for emotional support. There were kids who would just burst out crying. They would be out for a while. So for them, they wanted to be angry with the brokenness and humanity. Even though I may have called them a friend, they are really strangers. You don't know really what is going on in their lives" (26).

CF - Umm.. like when it happened I don't think anyone went back to school for a couple of days. They canceled school for a couple of days because there was no communication...you couldn't talk to anyone really. It was just dead quiet; no one really talked with each other" (9).

\section{B. Change of worldview}

The following quotes reflect ways in which the events of September $11^{\text {th }}, 2001$ affected participant‘s outlook on living in the U.S and/or in New York City.

BK $¥$ You know, it's ridiculous that we would be hit by something like this...I really believed that living in the U.S.A, that like, no one would be able..I thought I was in the safest place. It's impenetrable! No one hits the U.S...for me, I think it was more like 
my security of the government and my security of the country was shaken...where I lived...just that world view changed, that paradigm changed in my life" (5).

EC + became more cautious...just things around me, my surroundings... what is going on around me...My level of awareness went up" (7).

DJ It didn't like...change my world view or anything. It didn`t impact me...I think for most of the New Yorkers, this was shocking. New Yorkers had people that were directly affected. Families lost people, it`s a personal event. It definitely hurt people. It definitely hurt us. It was damage to the country, physically and mentally" (9).

RK Everyone is on edge you know? No one knew what was going to happen next. Everyone thought like it was a huge attack on America and maybe somewhere else in the country, another planes crashes or bombs go off' (8).

CF described how the city changed and her awareness went up. $\mathrm{It}$ 's weird living in New York City and seeing everything like this because... it took a toll on the city itself you know? There are police and cops everywhere you go. Any holidays or anything huge, security is crazy! (14).

GJ discussed how she used to pass by the twin buildings all the time. She passes by the site on a daily basis now and she feels sad that she no longer has memories of the buildings and the times she spent there with her father. It was more about something was there and not its now. Things are different now. We got crazy with security and it affected our lives... and also every time there is terrorist warning, it affects my commute with traffic" (24). 
RK - Aikes me feel safe about security, but at the same time, people just can't stop their day because oh let me not go to work because of 9/11. People remember, but life goes on. That is just how it is" (15).

Since 9/11 occurred, there have been many changes in New York City, for example the level of security and the presences of police officers, especially around the anniversary time of $9 / 11$. For some informants the event changed their outlook on security and belief in the U.S.

\section{Personal Connection with the event}

This theme is composed of two subcategories: 1) having no personal ties and 2) having personal ties to the $9 / 11$ event. The first subtheme reflects not having a personal connection to the general physical location the city", to the individuals, or the buildings themselves.

BK spoke about not being connected to it $^{\star}$ (World Trade Towers). —-Hidn't have any personal ties to it though. Not one personal to me. I wasn't involved in the city or anything like that" (4).

EC + guess it wasn't personal for me... and that I was just indifferent about it. I didn't lose any family members or even went to the city that much. So there was no connection there. You know? Stuff like that...most of my world back then revolved around my school work and my friends. I had no reason to be in the city (pg 5). 
$\mathrm{RK}$ hmm. I don't think I was that connected to the buildings. I mean don't get me wrong, that day everyone was, I think that because there was no one I knew that was lost or a part of that. I was not as connected or affected by the event as a lot of other people" (7).

DJ For me the whole event was a little bit... sort of like, a distant history in the making. It wasn't personal for me (7)..I think I received closure in like two days...And not because I am belittling the event. But because it happened and I dealt with whatever I felt. I had other issues to worry about" (25).

The second subcategory within the theme of connectedness is reflected for those who felt connected then, some of whom still do. GJ Ididn't personally lose anyone..um..but I had friends who did. One of my good friend's dad was a fire fighter and he lost his life saving people that morning...so I think a lot of lives were affected in my school alone. Friends I knew lost their loved ones that day...it sucked... Frealize that my memories there went away. There isn't much to remember from there anymore. It's just weird because I had moments there. Basically, now all washed away in a sense" (18).

GJ had many childhood memories of going to the World Trade Center buildings with her father and that was destroyed when the buildings fell. She continues, Ido feel connected to it because people around me were clearly affected by it. I see them almost every day and they lost someone that they loved." (9)

NY mentions his direct connection to the event. Iremember how tough it was to get a job for everybody. I know for my parents it was hard for them to find work. After 
the store got smoked in and business started to fail within weeks of 9/11, we didn't have much to look forward to. Income was an issue. I remember for me...I was working and going to school part time. I worked at a ice cream store. So at the time I decided to work full time. It was hard because I got lucky too. I was lucky to find full time work...most kids around my age back then had trouble finding part time work you know? For my parents...man...it was tough restarting...they couldn't really do anything" (13-14).

AR was directly affected by the event. His parents had to close their store, like my parents, due to lack of business. It was tough times... one year is a long time in a business...think about it. Because they dipped into personal savings to keep the business running and hoped for the best. Rent went up and less people started to come in. I remember because the mayor said on the news, to buy and life your life ${ }^{6} . .$. matter of fact, I think the majority of the population did the opposite" (11-12).

\section{Coping}

When asked about coping with the event, only two informants reported they felt the need to cope. The others mentioned coping, but in a more indirect manner and often they related it to a matter of being respectful to others.

EC It wasn't personal mourning. It was more like the state I needed to be in. So for me, nothing to mourn per say. Out of respect for others, I mourned with them. I tried to relate to their feelings and just be open about what was being said" (12).

GJ Ithink my type of coping was from the outsider's perspective because it wasn't...I wasn't...I did not directly get affected by it" (24). 
RK Ithink I coped knowing that everyone that I knew, including friends and church members did not lose anyone. I think that helped knowing that no one I knew was lost. Umm...I think that was my way of coping. So I personally didn't cope. Don't get me wrong, I do feel bad for the people that lost their loved ones" (15).

DJ ŁIdidn`t take anything away from my life. So it was more about being available for others. There was no coping" (25).

AR acknowledged he was angry and wanted to do something about the attacks, but denied experiencing a coping process. $\sharp$ mm...I don't think there was any coping for me...um yeah...I don't recall any uhh...process like that for me. Granted I was angry but eventually I...it didn't have a long effect on me" (16).

CF Well honestly I can't say that it really...dramatically affected me. Of course I was upset, but like I didn't know anyone that was physically in there you know?” (13).

NY commented about what he did the weekend of 9/11. - My coping was going to church that weekend, wasn't sure if you were there. We just prayed for the lost ones and their family members...for safety and wealth...there was a lot of pain" (7).

In terms of coping, BK shared his thoughts right after the event. —-mean I would say I didn't really cope. I would say just through Christ. We had a 9/11 memorial service to just pray for the country, to just pray for the people that were lost and for our families. Some people really had to share their minds...we gathered people to pray and seek shelter" (6). 


\section{III: RELIGION}

The third major category was religion. Examining the data two patterns emerged: those who reported experiencing/ having religious reflective thoughts and those who indicated 9/11 had no effect on their beliefs, attitudes or religious practices. First, BK and DJ had religious reflective thoughts during 9/11 related to their religious beliefs, attitudes, and behaviors.

For BK, 9/11 was a turning point in his religious beliefs. It represented...like I said before me security, my beliefs, and my trust. Like any time there is some type of crisis, you evaluate your beliefs, you reevaluate your life. You reevaluate just how you live your life and I guess 9/11 was that kind of thing for me, so I wouldn't mean detached. What I mean is, I guess I would say is I am more detached to trust any external support. Like the government support. I believed that this was the safest place in the world. What it (9/11) did is lead me towards more Christianity and strengthen my relationship with God. Because it helped me truly see that you can't trust an organization or trust the place you live...things can fall apart instantly, at any time, at any moment... You know you can build your life up and all fall apart...but what helped me realize and helped me was to look towards God. He is the only one with the answers to this and it actually strengthens my faith, rather than weakened it" (8).

For DJ Iwas wondering if the world was coming to an end. I didn't think it was really coming to an end but... and then I went into thoughts like if it were...did I do enough as far in terms of leading people to Christ?...I think my perspective in general about things that happen like this, when we die, it comes down to whether we are saved 
or not. I mean it was tragic what happened. I thought it was sad. (8) I mean it's a religious war right?! When you can't understand something, you blame it on the divinity. In this case, we blame it on the enemy. There is always an enemy right?” (22).

By contrast, the other informants comments reflected the event had no direct effect on their religious beliefs, attitudes, and/or practices.

For EC, 9/11 had no relation at all to his Christian beliefs. Umm, no, not at all...I think a lot of people went to church for comfort but me...I didn't come to Christ then. I came to Christ actually seven years after $9 / 11$, so umm...I don't think $9 / 11$ rocked my faith or had any effect. I went to church, but didn't really pray or believe in Christ then" (11).

GJ $9 / 11$ did not have an effect on my religion at that time because my religious faith wasn't that strong at that time. Like you know, I was born into Christianity. I just know that I wasn't into church at all that early in high school" (22).

AR $U m$... for me back then, I was never that religious. I believed in God, don't get me wrong...uh, it didn't make me more religious or less religious...there was not a stand-still with me...It didn“t do anything to my religious beliefs” (15).

NY Iguess it's always been the same. I wouldn't say it has gone up or down really. It's about the same really...9/11 didn't have anything to do with it. I still believe what I believed ten years ago...I don't think it (9/11) has to do with religion. To me, religion is someone or something you believe in. I don't think 9/11 would make much 
difference in people s faith or way of praying etc. I don't know, maybe for some people? Just not for me (19).

For RK, 9/11 did not directly affect her religious beliefs. For me, one I haven't lost anyone or know anyone who lost anyone that was a part of that...but it is not the same for others...also I think it was because...for me I always believed that if something happens, there is a reason behind it" (13).

CF also talked about how the event had no relation to her religious beliefs. She talked about attending MBS church as a teenager. When asked whether $9 / 11$ had any effect on her religious beliefs or identity, she replied, Idon't think so. I am not really religious anymore. I was a Christian back then (referring to pre-9/11)...(11).

The findings reflect that only BK and DJ‘s religious position was directly affected by $9 / 11$. BK became more religious after the event and he reevaluated his belief system. For BK the event had made him realize that only God has the answers and trusting external supports' was not the answer. It (9/11) broadened the fact that ok, I said I put my trust in Jesus, but I put my trust in these people, these types of institutions, and these types of things...they failed. _Why do I feel this type of anxiety or insecurity“? That question helped me shift through and work through my faith" (12-13). DJ reflected upon whether he did enough as a Christian to lead people to Christ.

As the foregoing suggests two individuals commented on how the event impacted their religious identity and attitudes. However, quotes from the interviews revealed that 
six informants perceived there was no connections between $9 / 11$ and their Christian religiosity.

\section{IV: 9/11 TEN YEARS LATER}

In the last category, informants shared their thoughts and opinions about 9/11 and what the event meant to them after ten years. Two themes emerged across interviews: the idea of moving on and finding closure.

RK thave gotten over 9/11, because it‘s just a memory for me now. It's not something that I relive all the time. Like I stated before, it happened and I've moved on. I work in the city!" (16)

$\mathrm{CF}+$ guess most of us have moved on from that situation. I can't speak for everybody, but for the most part, no one talks about it (9/11) anymore. Honestly because it was the ten year anniversary it was a big deal" (15).

NY In a sense I've been over it...but every year that $9 / 11$ goes by, when it comes around, I still have memories of that day. As time passes by, it‘s just a memory now, you know?..anytime I think of $9 / 11$ or hear about it, it just brings back memories of New York" (12-13).

EC - Wll because I am not personally connected to the event, I don't have anyone overseas, I lost interest...I kind of got closure when I found out we captured Osama Bin Laden. But other than that, I don't think I need closure" (13).

GJ Ithink I received closure in the sense that...there was no point in time where I thought _yeah. It happened.' ‘..it was about as more time passed by...it sort of um..it wasn't the topic of the day" (15). 
AR discussed receiving closure after the first year anniversary. It was a symbolic image. I remember watching the news. You can see the memorial site with the lights out...it was well thought out...those two strong beams of light meant something. I think it means a lot to people. Makes me realize that people are still here now, one year later" (17).

By contrast, CF commented Idon't think I'll ever find closure for what happened. So many lives lost..some of them even, you know, just went to work on an average day...I don't think I'll ever find closure for it. But, I mean you just kind of have to deal with it. It happened, you have to move on. Just have to remind myself that at any instance, something can happen. You always have to be aware and just don't take things for granted really" That's how New York City is" (13).

BK reflected Iwould say I'm more detached to the whole 9/11 crisis...I mean it drew some interest, but to be honest with you, it didn't really matter to me as much as it used to be. I mean because I am always in the city...I travel to the city and I see ground zero slowly being built...so its, I guess, it's just another day for me. (8)... I mean I respect it. I appreciate the memorial and what has happened with the firefighters and all that. But other than that like, it doesn't hold as much significance, like any other day. (14)...I think I can say I'm over it (9/11). I'm over it. Personally in my life, it's not a big deal"'(15).

EC Ithink we will always remember where we were, but to be honest, it's probably losing a lot of its luster...because this year is different, because society puts great meaning into anniversaries and number and stuff...so the media was driving it..I think that it came to my mind more, but like for me because I wasn't personally connected to it...9/11 is just a day that comes by..and the first thing that comes to my 
mind about the event is not the twin towers, its just $9 / 11$. For me $9 / 11$ was just a day that we need to remember and that the day a lot of people sacrificed to help those in need...it's like honestly, the past five years I have forgotten about it...and like this year, even before anyone mentioned it was a ten year anniversary, it didn't cross my mind" (9).

RK We think that no one can ever think of attacking it [the buildings], let alone the U.S. (7)... It's just now, I am now freaked out every $9 / 11$ that something is going to happen. It's a memory that people will never forget and people respect." (11)

DJ For me personally though, like I said...the underlying idea was, not because I was so spiritual or anything, it was something like this...it can happen at any time and it's not about if it happens, it will happen...I'm not sure whether it was because I wasn't personally connected to it or that it's just how I am.” (9)

\section{SUMMARY}

This chapter has highlighted some of the lived experiences of the former Marn Baek Sung church members. The chapter opened with the demographic profile of who and where they are now ten years after the $9 / 11$ event to provide the reader with a contextual background of the informants. The initial emergent themes and patterns were organized into four major categories: I: The day of the attack. II: Post 9/11. III: Religious Impact. IV: 9/11 ten years later. There were several subthemes within most categories.

The first major category highlighted the day of 9/11. I learned of the informants whereabouts during 9/11 and how being in school, and of a certain age, played an important role in their lived experiences of the event. Age of the informants at the time of 9/11 emerged as important because of the difference it appeared to make in their 
perception of and attitudes and beliefs about the attacks. Informants themselves acknowledge the impact of their age when 9/11 occurred. Next the discussion covered how each informant_found out ${ }^{\star}$ what was going on during 9/11, either through teachers, rumors (word-of-mouth), and/or technology. Informants noted the inconsistencies of available information and lack of reliable, working technology at the time. Then I explained their initial reactions to $9 / 11$. The informants had similar immediate reactions and thoughts, such as 9/11 being chaotic and as if it were a movie‘. Emotions ranged from fear, anger, panic, and being vulnerable. I also highlighted several informants lived experience of seeing the burning buildings.

The second major category, post 9/11 was then discussed including what life was like in the days immediately after $9 / 11$ as well as whether the informants had any personal relationships to the event, and if the informants thought they had to cope with 9/11. Informants discussed watching the news throughout the day and not returning to school for a few days after $9 / 11$. Several informants spoke about not having any direct personal ties to the event and not losing anyone they knew while others highlighted coping with $9 / 11$. The discussion of coping with the event included discussion of some actual behaviors, but primarily informants' reflections on needing or not needing to cope. The third major category dealt with religion and whether informants' religious position was affected by $9 / 11$. Two of the eight informants indicated that the event directly affected them, creating stronger religious beliefs, while the other six mention no direct impact. Finally, I discussed the fourth major category: what is being communicated about 9/11 after ten years. Informants focused primarily on moving on' from the event and finding closure ten years later. A couple of informants indicated no closure, but most did. 
The informants also discussed the different effects the media had on their current experiences of the $9 / 11$ anniversary.

Based on the findings reported in this chapter, chapter five shifts to interpretations of the findings with links to the literature. The study limitations and contributions as well as implications for future research are also provided. 


\section{CHAPTER V}

\section{DISCUSSION AND CONCLUSION}

\section{INTRODUCTION}

The purpose of this study was to investigate the lived experiences of a group of second generation Korean-American Christian residents who were present in New York City at the time of the attacks, September $11^{\text {th }}, 2001$. The guiding research questions of this study were: RQ1: What were their life experiences of 9/11? RQ2: Was their religious status affected by the event? RQ3: What is being communicated about 9/11 after 10 years?

Each research question investigated how the informants understood 9/11 during and after the attacks, how the event did or did not impact their religious faith/beliefs, and what is communicated about 9/11 after ten years. The research design included eight individual interviews with second-generation Korean-Americans who were members of Marn Baek Sung church at the time of 9/11. The stories that were told in the interviews were determined to be reflective of making meaning of 9/11 and how it impacted their philosophy of life, and/or manner of engaging in their personal and professional activities, families, relationships, and community.

Based on the findings from the previous chapter, this chapter begins with a discussion section with my own interpretations of the findings and relevant links with the literature. Expectations that were met and not met after all interviews were completed and 
transcribed follow the discussion. After that, I review the study limitations, contributions of the study, and implications for future research.

\section{DISCUSSION}

This was a phenomenological study, which emphasized the informant's point of view and is subjective (Husserl, 1962). I wanted to understand the ways in which 9/11 impacted the informant's lives and religiosity, from their frame of reference. As a qualitative researcher, I believe that there are multiple ways of interpreting experiences through interactions with others, and that it is the meaning of our unique experiences that constitutes reality. This reality is consequently, socially constructed“ (Bogden \& Biklen, 1992). It is important to acknowledge the interpretations made in the following discussion were made through my perspective, though constantly keeping in mind the informants descriptions of their experiences.

The alternative interpretations are affected by several factors including; informants' accounts, my own personal experience of 9/11 and how it impacted my life, and the fact that I was a former member of this particular cultural group. Having attended Marn Baek Sung church before moving at the age of 18, I spent a lot of time with these informants during my youth. I had known most of the informants since I was in kindergarten and felt a sense of belonging with that group for many years. Therefore, I was not worried about openly discussing the topic with the informants and was comfortable during the interviewing process. Interpretations are also affected by my ability to utilize the phenomenological steps (See Chapter 3) in the interpretive process. I had the unique opportunity to have both an insider's and outsider's perspective (Patton, 
2002). As mentioned above and previously in the methodology section, (See Chapter 3), my assumptions and expectations were identified prior to the interviewing process and known prior to analyzing the transcripts.

The informants talked about 9/11 within the narratives process of story-telling. Instead of a structured interview based strictly on questions and answers, the interviews turned out to be a long narrative of their experience of $9 / 11$ as a teenager, how they understood the event, and the different ways 9/11 impacted their lives. Two informants mentioned how they have not had an opportunity to disclose such personal information and reflections of $9 / 11$ with anyone else.

John Stanfield, in his book titled, Rethinking Race and Ethnicity in Research Methods (2011) states that narratives gathered through qualitative methods, such as individual and group interviews, allow for space for stories to emerge while participants speak in their own words without being boxed in by specific answers. They also let the stories be retained in the words of the participants during data analysis (239).

Posta (2010) further adds to the importance of narratives and stories for families of 9/11 victims. She explains how the stories have become part of a larger social consciousness. Felling stories helps to shed light on one's identity, relationship to others, values, and hopes" (p. 26). Fisher (1985) proposed that human beings can be understood not just as homo sapiens, but also as homo narrans in order to more comprehensively categorize human experience. The informant‘s narratives were reconstruction of their memories of $9 / 11$ and expressed how they made meaning out of these events. 
RQ1

The first central research question of this study was about the informants lived experiences of $9 / 11$. What the informants experienced during and after $9 / 11$ is complex, with many interweaving categories, and though similar, no two informant‘s story was exactly the same. The importance of making sense of 9/11 varied notably between individuals, and the desire and ability to do this was not uniform. Although it is not possible to discuss each category in great detail in the discussion, a number of overarching themes emerged that appear significant.

\section{High School}

The first overarching pattern found in the interview transcripts was that each informant, including myself, was in high school during the attacks. It is crucial to acknowledge where the informants were the day of $9 / 11$ to provide better contextual understanding of how they experienced the event. Being in high school at the time of 9/11 is important to discuss because it incorporates other categories such as location and age.

The location of self and location of significant others in their life at the time of 9/11 is crucial to highlight because proximity of the World Trade Center, in relation to the informants school location and loved ones, had a direct affect on the informants that particular day. For example, EC was in a private school in Edison, New Jersey during 9/11. He and AR were the furthest away from the World Trade Center in comparison to the other six informants and it reflects in his experiences. He spoke about his disconnection to the city itself because of being in a different state. Kind of far from downtown...In New Jersey, it is like an hour and some minutes away from the city. I 
knew I wasn't too close to the city so I wasn't too concerned. All our family was home. No worries in New Jersey really" (5-6). AR also commented Everything was like... unbelievable because I wasn't there. And I was nowhere in near sight of it. I was in another borough" (5).

RK talked about her worries as she was at Tottenville High School, which was on opposite end of Staten Island and did not face downtown Manhattan. It was too bad because Tottenville is on the other side of Staten Island, so I knew nothing was going to go down near me. I was just really worried about my brother traveling in the city at the time and how my parents and younger brother were going to make it home from the other boroughs (5).

NY and GJ who were located closer to downtown Manhattan, reported seeing and smelling the burning debris from the buildings. Both informants' school location on Staten Island, was facing the city. NY reflected + know that New Dorp High School was close to the shore of Staten Island and you could see and smell the smoke coming from the fallen buildings. When the first plane hit, you can see that clouds going across Staten Island and when the second one hit, Staten Island just went dark" (3). GJ recalled The smoke that traveled to Staten Island... It made me realize Staten Island is closer than I thought. I mean, the buildings were right downtown and we did live closer to that area. Yup, so one thing I noticed was the smoke outside. It was thick and black outside and scary. Like a really dark cloud...crazy scene" (13-14).

DJ was the informant closest to the World Trade Center because of the location of the school he attended. He was the only informant in downtown New York City when 
9/11 was taking place and had to walk home because public transportation was not running during $9 / 11$. He talked about his memories while walking down towards the World Trade Towers. You know, we just heard updates by...calling people and asking around. People were all over the streets. My cell phone worked up to a certain point and then I remember them not working” (5).

Locations of loved ones were also a determining factor for the informants during 9/11. As highlighted in Chapter IV, several informants had siblings, parents, and/or friends located in downtown Manhattan the morning of 9/11. RK had two brothers traveling in New York City during 9/11 and not being able to contact them or know their whereabouts made her feel even more anxiety and stress. Iwas really worried about my brothers when I was in school waiting for more details on what was going on at the time. I panicked for a while because no one in the family knew where my brothers were and my parents were completely stressed...My youngest brother is sort of lucky to be alive because he was running late to work that morning and he was actually stuck on the subway, on his way to work. He was stuck on Canal Street when all the public transportation shut down...My older brother was stuck on a bus somewhere in the city. I didn't find out where he was until later in the afternoon. My biggest concern was getting home safely" (6).

CF commented - h, I automatically thought of your parents and parents. (Both my parents and a mutual parents worked within a few block so the Twin buildings.) I knew how close they were to the buildings. So that was my instant reaction and concern. May be you guys were ok, but I just did not know for sure. I remember calling my mom to check if see had heard from you or your parents. 
GJ was concerned about her brother-in-law during 9/11. — @e of the first things we did was call family members to make sure they were ok. With my brother-in-law that worked there, (Twin buildings) we didn't know what had happened to him of where he was at the time. He ended up stuck on a train and had to walk back home to Brooklyn...Everyone he worked with evacuated the buildings in time and so none of his coworkers got hurt thankfully" (7).

Age

Acknowledging that each informant was in a school setting at the time is important to acknowledge because it made me realize their lived experiences were not from an adult's point of view, but from a teenager's point of view, something that I did not fully appreciate until after the interviews were transcribed. At the time of the attacks the informant's age ranged from 14 to 18 years old. The informants had to go back in time and recall their teenage memories, where they had no control of their surroundings and looked towards others for help and guidance. It is interesting to note that several informants realized the impact age had on them at the time of 9/11 (See Chapter IV). Some informants acknowledged that they were naïve, not up to date on current events, preoccupied with personal matters, and these factors seemed to affect their comprehension of and reaction to the unfolding events of that day. They were focused on other issues, such as good grades and studying for the SAT's.

As DJ noted It (9/11) provided a distraction for me. (laughs) Compared to 9/11, my personal home problems were more important and relevant” (10). EC - Most of my world back then revolved around my school work and my friends. I had no reason to be 
in the city...Because I was 15 at the time and I wasn't up to date with politics or what was going on overseas. When 9/11 happened, I didn“t know what to think" (5-6). GJ discussed how her age affected her experience. Fjust thought it was a big accident and I don't know why I thought it was a big accident. I think my immaturity had to do with it. Because we were what 15 at the time? We didn't witness a terrorist attack before and it was all new to us" (8).

Along with all the informants being in school at the time, technology also played a factor in their lived experiences in two main ways. The first was getting in contact with loved ones during and after the event. RK, GJ, NY, and CF, as mentioned previously, had relatives or friends in the city when 9/11 unfolded. The second way technology was a factor in their experiences was retrieving disaster information and the speed in which information is communicated.

Out of the eight informants at the time of the attacks, only CF had access to the internet while at school. Petrides High School was considered a high tech` school, which provided most of the students with Macintosh laptops for the school year and internet access throughout the school property. Having a computer during 9/11 impacted her experience as she could get online and find out what was going on. No other informant had this type of technological advantage. CF - So it was a high tech type of school. So around 10:30am, everyone in the school knew what had happened. Because we were online and in third period class...It wasn't until news started to come on AOL. We all started to watching the news and searching online for the facts" (2). Even though CF had 
access to the internet, she did mention the impacts of cell phones not working. There was no cell phone reception. The TV's...some channels were not working” (3).

Access and usage of technology during the event played a role for the informants, as it heightened the anxiety and stress for most of the informants. The way in which information was received during 9/11 played a crucial part in their experiences. Disaster related information to the informants was mainly through word of mouth and all but one informant had to rely on the school faculty for details and confirmation of the attacks. Immediate details were not available.

RK reflected $\Psi$ think because so many people were trying to call each other in New York that it was just bombarded with calls. Like every time you made a call, it wouldn't even ring for some reason. It was jammed up or something with the service" (4). NY When I got home, I remember trying to call my parents and the phones weren't working though. It was scary because cell phones were not working. You couldn't make any outgoing calls. Couldn't call anybody” (4).

Marguerite Reardon (2011) from CBSNews, provides an account for the effects on cell networks during and post-9/11. She explained how during the event, there were several reasons why cell phone reception was terrible and the improvements that have been made since 2001. The network failure could partially be pinned on infrastructure damage. Cell towers were destroyed in the attacks, along with switching equipment used for landline phones. But another cause of the problem was the huge surge in traffic from people trying to find loved ones or letting others know they were OK" (CBSNews). 
Dean Praetorious of the Huffington Post (2012) notes how social media and technology have changed in the past ten years since 9/11. He points out, how in 2001, we did not have YouTube and Google News did not exist as well. He also mentioned -eell phones were virtually useless, phones lines were more than tied up, and in terms of communication, that was pretty much it" (The Huffingtion Post, 2012).

Finally, informants talked about experiencing the day as chaotic and confusing. RK commented It was a chaotic and confusing day. Not that many kids were paying attention in classes and we had a lot of kids being pulled out of class" (5). Additionally, they experienced fear and worry.

BK recalled - so once the announcements were made, that was the time when the students started to get really concerned. They started calling on their cell phones. There was just a lot of mayhem going on. A lot of worries and a lot of fears, especially because most of the students parents worked in the financial district and students were literally freaking out! They were scared out of their minds!" (3).

EC — Femember going through the rest of the school day, seeing a lot of people in paranoia...I guess a few classmates had relatives that were involved and so I saw a few kids crying" (5).

In all, the first research question as to how the informants experienced 9/11 centrally involved the effects of location of self and loved ones, what they experienced in school, the age factor, technology issues, and how the rest of the day unfolded. 
Dealing with high school students in a time of a crisis situation, I found similar reported examples of informants' use of narratives to make meaning of the tragic event of Columbine and events of 9/11. Although the attacks were different in scale and size, there are several comparisons between the two events. Hawkins et al, (2004) conducted a qualitative study of students and parents responses, two weeks after the April 20, 1999 Columbine High School in Colorado. The researchers interviewed four Columbine High School students and seven parents. Although the study had a small sample size, what the researchers found was that for all four students and most parents, there were similarities and variability in immediate emotional, cognitive, and social responses to the mass violence. After learning more about what had occurred in the school, most students and parents felt a large range of emotions.

Almost all of the respondents in the Columbine study recognized the challenges after the shooting had occurred. These challenges included lack of motivation for some of the children in school, knowing someone who lost friends during the shooting, and also the sense of security in their everyday routine. They previously felt immune to this type of incident. (Hawkin et el, 2004).

Similar to the shootings at Columbine High School, the informants in this study reported similar experiences during a crisis situation. Although the type of violence was different in both events, both events involved school students and their first-hand experience to a new type of crisis. In both situations, their assumptions about safety and security were seriously challenged or shattered. Like several of the students and parents in Hawkins (2004) study, my informants also discussed confusion and disbelief. BK 
commented + really believed that living in the U.S. that no one would be able to do something like that. I thought I would be in the safest place in the U.S" (5). EC commented $\Psi$ don't know if the right word is shocked, but it was surreal. I mean does that (9/11) happen in life? Who would do something like this" (5). GJ reflected $\Psi_{\text {don }}$ t know, like world tragedies and stuff like that. I don't know, it makes me feel uncomfortable and makes me really sad for the world and I feel so helpless" (8). RK spoke about her biggest concerns during 9/11. Tthink for me it was the safety of my family and my friends. Some of them were just completely cut off by it (9/11) and emotionally a wreck" (7). The reactions of the informants in the study indicated that 9/11 was perceived as posing a serious threat, not only to their lives, but to family and friends in downtown Manhattan. It also posed a threat to their notion of being invulnerable and their illusions of the world being a fair and safe place.

There are some other similarities between the experiences of both the Columbine shooting and 9/11 in this particular study. Both studies focused mainly on adolescents and their responses to acts of violence on a large scale. In both events informants discovered what was going on during the attacks through similar sources, which were through friends and teachers. This study mirrors the Hawkins article in that during the events, students relied on teachers and faculty members for safety and guidance. Initial reactions were similar as well: confusion, surprise, and disbelief. In both instances, after learning more in both instances reports of feeling scared and panicked emerged. Due to the fact that the informants were in school at the time and the technology was what it was today, finding out', what was going on further played a role in the chaos and enhanced 
the reactions that particular day. Recalling from my own experience of $9 / 11$, I think that not having the immediate safety of ones parents may have added to the anxiety.

RQ2

The second central research question of this study was about religion and whether 9/11 had any impact on the informants' Christian faith and beliefs. Informants reflected a range of responses from no effects to strong effects on their spiritual beliefs. Based on my personal understanding of each informant and data from the interviews, I arranged the informants along a continuum to better contextualize each informant's religiosity. The continuum serves as a tool to estimate informant's current religious status.

Figure 1: Continuum of religiosity

Most religious

Least Religious

BK, DJ $\quad \mathrm{EC}, \mathrm{AR}, \mathrm{GJ} \quad \mathrm{NY} \quad \mathrm{RK} \quad \mathrm{CF}$

At the left of the continuum two informants, BK and DJ clustered together. Even prior to $9 / 11$, I sensed they both had strong religious backgrounds and beliefs. I recall BK and DJ being at church events and leading worship on Sundays. Less than two years ago BK became a pastor and leads a new church called 180 Church. DJ holds multiple positions within 180 Church. Further towards the middle of the continuum are EC, AR, and GJ, who are involved and active members of 180 Church. They now identify themselves as Christians and followers of Christ. During the interviews, the three informants mentioned briefly about how they attended church, but did not believe in nor 
had come to Christ before 9/11. EC, AR, and GJ also mention during 9/11, their religiosity was not directly impacted and that they found their religious identity after 9/11. Next is NY, who attends a church in Beaverton, Oregon, but I would argue is not as _religious' as EC, AR, and GJ. There were periods of time when NY did not attend church during his teenage years. NY responded $\mathrm{Ht}^{\mathrm{t}} \mathrm{s}$ pretty much the same (his religious beliefs compared to 2001) I've always been a Christian..It's still the same as back then" (18). Moving toward the other end of the continuum are RK and CF. RK no longer attends any church, but -still believes in God and everything" (8). For personal reasons she stopped attending Marn Beak Sung church shortly after I moved to Oregon. CF left Christianity altogether a few years after $9 / 11$. She does not identify herself as a Christian any longer.

So the question is: Was their religious status affected by $9 / 11$ ? The study finds that two informants (BK and DJ) religiosity was directly impacted by the events of 9/11. Their responses lead me to think the impact was dependent on how strong ones religious position was in the first place. Growing up, BK and DJ were very religious compared to the other six informants from my point of view, and it seemed that Christianity was largely associated to their cultural identity as a child. For example, BK and DJ were both a part of the music leadership of Marn Beak Sung church and always involved in church community projects. BK and DJ had religious reflections during and after $9 / 11$, that helped strengthen their religiosity (see Chapter IV). Pargament (1997) argues that because religious beliefs tend to be stable, people confronted with a crisis are more likely to change their perceptions of the situation to fit their preexisting beliefs than to change 
their religious beliefs. For many people, religion is an important philosophical orientation that affects their understanding of the world, and that makes reality and suffering understandable and bearable" (Pargament, 1997). This statement appears to be true for BK and DJ. For BK, 9/11 strengthened his beliefs. What it (9/11) did is lead me towards more Christianity and strengthen my relationship with God. Because it helped me to truly see that you can't trust an organization or trust the places you live....and things can fall apart instantly, at any time, at any moment. You can build your life up and all fall apart. What helped me realize and helped was to look towards God. He is the only one with the answers to this" (8). He also talked about how he would speak to friends and family members at church the week of $9 / 11$ and also how he setup a prayer meeting. $\Psi$ was one of the leaders at church at the time so not to say it was my job, but...I felt responsible to be a good friend and just be there from them. I remember setting up a prayer meeting at the time. We had a 9/11 memorial service to just pray for the country, to just pray for the people lost and their families...we gathered people to pray and seek shelter" (6).

DJ talked about his thoughts on his Christian identity during $9 / 11$ and whether he did his work as a follower of Christ. The only think I was thinking about honestly at the time was I active in the church? I was wondering if the world was coming to an end. I didn't think it was really coming to an end but... and then I went into thoughts like if it...did I do enough as far in terms of leading people to Christ? Should I have told my friends about him?" (7). He also spoke about how 9/11 should not have gained or deterred Christians, but rather was an opportunity to acknowledge the brokenness in 
humanity. Thus, for two informants in this study, 9/11 further defined their religiosity and beliefs.

For six of the informants, there did not seem to be any relationship between $9 / 11$ and their religiosity and beliefs. EC reflected + came to Christ actually seven years after 9/11, so I don't think 9/11 rocked my faith or had any effect. I went to church but didn't really pray or believe in Christ" (11). AR commented For me, back then..I was never that religious. I believed in God, don't get me wrong, but there was not a stand-still with me. It (9/11) didn“t do anything to my religious beliefs" (15). For GJ $\rightarrow / 11$ did not have an effect on my religion at that (9/11) time because my religious faith was not that strong at the time. I was born into Christianity" and I actually left church for a while so" (21). So, although these three participants are currently active with the 180 Church of which $\mathrm{BK}$ is the pastor and DJ is centrally involved, none attribute their current involvement to effects from $9 / 11$.

Moving along the continuum, NY commented that his religious beliefs were the same pre-9/11 and post 9/11, and his religious beliefs had no direct effect from the event. Iguess it's always been the same. I wouldn't say it has gone up or down really. It's about the same really...9/11 didn't have anything to do with it. I still believe what I believed ten years ago...I don't think it (9/11) has to do with religion. To me, religion is someone or something you believe in. I don't think 9/11 would make much difference in people's faith or way of praying etc. I don't know, maybe for some people? Just not for me" (19). 
RK stopped going to church because of hypocrisy in the church. - Alot of people saying things about me...it was like a lot of judgments were being made during my college years at church. I just didn't want to be a part of something that people said one thing and acted on another thing or way" (17). Finally, CF chose to leave Christianity a few years after 9/11 but repeated that it was her personal choice and was not a result of the 9/11 event. Fwas a Christian back then (pre 9/11) and now I am kind of undecided. Not sure why though, but it has nothing to do with that 9/11" (11). These latter two informants who left their former church (Marn Baek Sung) and are not currently religiously involved, do not attribute their choices because of the events of 9/11.

The findings of this study both agree and disagree with Heerak Kim's discussion of the religious divide of Korean American Christians after 9/11. Kim (2008) wrote how 9/11 brought forward questions about communal safety and that Korean American Christians reacted in two ways following the event. The first was becoming more evangelical and involved in Christianity. The second reaction was to abandon the Christian identity. BK`s perspective reflected what Heerak Kim wrote. $\Psi$ felt like the crisis really brought out the questions that people had. It questioned people's faith at the time. I felt like it anchored people's faith or it either drew people away” (11).

A possible explanation as to why the six informants' religiosity was not questioned or affected may have been due their age and they were still developing their own identities. At the time of the event, the informants were still teenagers. AR, EC, GJ, and RK mentioned in the interviews about the relative strength of their faith and they did not come to Christ" prior to 9/11. For example, AR stated For me back then (pre 9/11) I 
was never that religious. Through my personal path, I would say I became more religious. Not because of 9/11" (15). This may have been due to their age. Ten years later, six of the eight identify themselves as Christians/ followers of Christ.

Sharon Kim and Heerak Kim both wrote about the new movement of second generation Korean-American Christians creating their own churches. Sharon Kim (2010) notes, how for second generation Korean-Americans, these churches are a hybrid third space to inhabit', and that these churches, by forming and inhabiting third spaces are challenging and blurring the boundaries that distinguish -ethnic" from mainstream" religion" (p.102). It appears that for the informants in this study living in New York City, who are active members of 180 Church, this church appears to represent exactly what these authors are referring to. Instead of mimicking directly from the parents' generation of Christianity, these informants are creating and communicating a new direction of Christianity.

Religion \& Coping

The study findings seem in agreement with Plante \& Canchola (2004) study on how, regardless of the strength of an individual's religious beliefs, it does not positively correlate with coping well. When asked about whether he or she coped in any way after 9/11, only BK and NY made brief comments on coping and what they did to cope with the event. For BK coping occurred through prayer at Marn Beak Sung church and through fellowship with others. BK + would say just through Christ. Through my church community. We had a 9/11 memorial service to just pray for the country, to just pray for 
the people that were lost and for our families. Some people really had to share their minds...we gathered people to pray and seek shelter" (6.) NY had to deal with his parents losing their business and had to work to support the family. NY commented -My coping was going to church that weekend. We just prayed for the lost ones and their family members...for safety and wealth...there was a lot of pain" (7). Both individuals went to church to cope the weekend of $9 / 11$, to pray and gather.

The study also found that half of the informants mentioned prayer during the week of $9 / 11$, but I regret not probing for more information as to the reasons for prayer. Prayer after a crisis event is highlighted by Ai et al, (2005) study on hundreds of high school students three months post $9 / 11$. The researchers found that of the 453 student sample, sixty two percent of the participants used private prayer to cope with 9/11. I assume that although it was not directly stated, the informants also used prayer to cope with $9 / 11$.

The other informants mentioned how they felt no personal need to cope, but did have reflective thoughts about being respectful to others and being there for others. For example, EC commented It wasn't personal mourning. It was more like the state I needed to be in. So for me, nothing to mourn per say. Out of respect for others, I mourned with them. I tried to relate to their feelings and just be open about what was being said" (12). RK stated + think I coped knowing that everyone that I knew, including friends and church members did not lose anyone. I think that helped knowing that no one I knew was lost. Umm...I think that was my way of coping. So I personally didn`t cope. Don`t get me wrong, I do feel bad for the people that lost their loved ones" (15). 
Several times, informants also mentioned not losing‘ anyone. I think it is because the informants did not experience any deaths due to $9 / 11$, they did not feel as connected to the event such as myself. Granted I did not lose my parents during the event, but the outcome of losing the family business and moving to Oregon, had a direct effect on me. For example GJ stated — did not get directly affected by it, as in personal. I mean I did, but not in the way like someone close to me died that day and affected that way. I would have to cope with that lose and grieve over the lost ones" (24). Coping may have been through communicating with others as mentioned by Marl Schuster, et al, (2001) as several informants mentioned simply talking with others about what had happened, but not necessarily in a religious context.

Another possible answer as to why the informants reported not coping or needing to cope with $9 / 11$ was simply not being able to remember what they did exactly ten years ago to cope with the event. I would argue it is easier to recall their whereabouts during the event, compared to recall the following days of coping. As Ai et el, (2005) explains over seventy five percent of their sample chose some sort of prayer to cope. In this study prayer is mentioned a few times from the informants, but it is not certain whether it was used for coping purposes. Perhaps they did something with their families, friends, and/or church, but because it has been a decade since the event, memory decay could have been a factor.

The informants may have also coped with the event in a more indirect manner, such as being with family members at home, watching TV for the newest updates, or by going to church. GJ talked about her experiences watching TV the night of 9/11. Ido 
know that at night, all I did was watch the news. Like all night long I just tried to figure out what was going on. It was pretty freaky what happened. I remember watching sad stories of kids stuck at airports and families crying over loved ones that died that day. Not to sound mean or anything, but it helped knowing that I didn't experience death like thousands of others that day" (7-8).

RQ3

The final research question addressed what is being communicated about $9 / 11$ after ten years. With an open-ended question, I received insightful thoughts and opinions. A common theme that arose from the interviews was that the meaning of 9/11 ten years later is not what it used to be. More specifically, informants talked about issues of security and traffic during the anniversary. The findings from the study seem to agree with Mark Juergensmeyer (2004) and Grace Palacio (2005) about vulnerability after 9/11, in that, this event made us realize what Mark refers to as the dark-side' of religion and how it can impact the world. For this sample, $9 / 11$ has changed their lives and brought to life the dangers of certain religious groups. The event also brought feelings of anxiety and vulnerability as their sense of safety and comfort was threatened. Several informants mentioned how there is a visible increase in security in New York City since 2001. This appeared to be true for most of the informants. Informants also spoke about the heightened security during the anniversaries and being more aware of their surroundings. For example, RK comments answering. -Now, it‘s like everyone‘s on edge. There is more security around. During the timing of the anniversaries, you will see on the news and in the city how cops are just everywhere. Tunnels and subways are being checked out 
for any threats" (14). GJ added Things are different now. We got crazy with security and affected our lives in the sense that if I go on vacation, there will be additional checks! And also every time there is a terrorist warning, it affects my commute" (24). EC noted that his level of awareness went up. Ithink I became more cautious. Just things around me...my surroundings... what was going on around me...my awareness level went up. There was talks about more attacks, so I remember being careful" (7).

CF also commented how New York has visibly changed post 9/11. — bu see police and cops everywhere you go now. Any holidays or anything huge, security is crazy. Like even past 9/11 anniversaries, there were check points, street blocks and bomb sniffing dogs. I' $\mathrm{m}$ pretty sure if this was in any other state, people would be freaking out! Yeah...but in New York, people are just like they are searching for bombs. Oh, ok, yeah, check my car'. It's just weird that it came to that point ten years later, that we are actually ready for it" (14).

I experienced firsthand the increase in security and reality of the changes in New York City. To witness the tenth anniversary memorial service at ground zero, I took the Staten Island Ferry to downtown Manhattan. In my 18 years of living in New York, I have never been stopped by a police officer while walking to board the ferry. When I arrived at the ferry terminal, I recall there was a line of police officers with K9-unit dogs. I was told to present and open my backpack before boarding. After being cleared and taking the ferry to the city, I was not permitted within two blocks of the site because of security protocol'; I was carrying a backpack (with thesis materials) and could not enter the area. 
Another emergent theme during the 9/11 anniversary is the public memory and thoughts of never forgetting what had happened that day. Four informants spoke of this, BK said + know that I will always remember that day though. 9/11 will always be etched in my mind, the moment where our country was attacked by a foreign country. Reminds me that no one is safe. Anything can happen. Really anything!” (21).

CF reflected Idon't think I will ever find closure for what happened that day...9/11 was the most heart breaking thing in the world to watch. I've been in that building maybe two or three times before 9/11 happened. So I know how beautiful the building was" (7).

GJ Ipass by the site everyday for work. I see it being built and it's just weird. I used to walk in those buildings and now they are just memories. It's so sad. I used to spend a lot of time around the buildings" (6).

NY Well every year on 9/11, no matter where I am..I still think about what happened. I will always take a moment of silence to think and reflect...think about past memories and pray for the loved ones that pasted away. Just a lot of memories of the buildings" (19).

On the other hand, what is also communicated about $9 / 11$ ten years later is that it does not hold the same meaning or value today, compared to 2001. The informants' responses seem to reflect earlier research findings (Barna, Pew, \& Gallup) that things have gone back to normal, and simply life has moved on. As DJ commented, For me what I observed was people getting back to a steady routine, getting back to their lives. It 
(9/11) made it scary, maybe scarier. I think New York did a pretty good job, getting back to its feet. Not only that, people (laughs) had lives to live you know? A lot of my friends had bills to pay" (11). CF commented You can just tell the community of New Yorkers. We had no choice but to start up again right? Besides the cleaning efforts, it was busy as usual days after 9/11”(9). Posta (2009) further adds to this trend, While many individuals continue to suffer from the aftermath of the events of September $11^{\text {th }}, 2001$, life has moved on. For most people, airport security checks, national terror threat levels, war, and 9/11 anniversaries are the only reminders of what happened on that tragic day" $(\mathrm{pg}, 16)$.

One possible explanation how or why many of my informants state they are = over $^{6} 9 / 11$ is because they still live and work in New York City and see the site change on a daily basis. Other than the informant who lives in Oregon, RK and CF are the only informants that do not attend 180 Church, but still work in the Manhattan. As Foner (2005) contends, For many New Yorkers, life in the months after September 11 was mainly business as usual...Most New Yorkers did not know anyone personally who was killed in the attack, and their everyday lives went on much as before. Even in the immediate aftermath of September 11, New Yorkers responded differently, in large part of the basis of where they worked and lived in the city" (Foner 2005).

One of the last questions I asked in the interview was about the informant's day on the ten year anniversary of $9 / 11$. The anniversary date was on a Sunday and I simply asked if they did anything in particular in honor of 9/11. Only two of the eight informants did anything related to $9 / 11$. AR and NY both had a moment of silence and prayed 
Sunday morning for the families and lost ones of $9 / 11$. AR woke up early to head to the city for 180 Church. He had a moment of silence while driving to downtown Manhattan, on the way to church. Just being grateful and thinking about those that passed away" (19). NY commented fust went to church...had a moment of silence to remember what happened that day...that's about it" (31).

For the remaining informants, they did nothing special. ‘ RK, CF, and GJ discussed how they did nothing out of the ordinary and stayed home. BK commented Nope. Went to church and saw you there! Then ate lunch and went to night service" (34). EC reflected - On Sunday I went to church and um...it was a normal day. Nothing special” (29). DJ commented +went to church. I was (laughs) actually worried about traffic from the additional security" (27). I was surprised to see these informants had moved on to the extent they seem to have, and did not do anything particular on the ten year anniversary date. When I attended 180 Church on Sunday, the anniversary date, there was no special prayer made or any mention of $9 / 11$. As noted by the Barna group After the attack, millions of nominally churched or generally irreligious Americans were desperately seeking something that would restore stability and a sense of meaning to life. Fortunately, many of them turned to the church. Unfortunately, few of them experienced anything that was sufficiently life-changing to capture their attention and their allegiance... Our assessment is that churches succeeded at putting on a friendly face but failed at motivating the vast majority of spiritual explorers to connect with Christ in a more intimate or intense manner" (the Barna group). 


\section{Identity Shift \& 9/11}

I interpret that the informants' identity prior to $9 / 11$ as similar to my own identity. I attended Marn Beak Sung church for years prior to $9 / 11$, but did not truly believe in Christ or had strong religious beliefs. Marn Beak Sung felt like a second home to me and although I did not ask what Marn Beak Sung meant to the informants, I think they would agree with the statement. 9/11 completely changed my view on Christianity and therefore, it gave me further incentive to pursue this topic and find my own personal answers to _Why let this happen God? Why allow such horror to take place? I have wondered for years how my fellow Marn Baek Sung church members experienced 9/11 and if it affected their religious beliefs like it did for me. It turns out for the most part, the informants and I share some similar stories of 9/11 and how it unfolded days and years later, however not when it came to religion. The informants did have unique perspectives as to the impact the event had on their religious beliefs. I thought at least one informant would report a negative impact on their religious beliefs because of $9 / 11$, but that was not the case as it had been with me. It seems that compared to the informants, 9/11 had a tremendous impact on my religious life.

Since 9/11, their identities have changed and the effects that 9/11 are complex and real. As stated previously by Collier (1997) ethnic identities are constantly changing, negotiated, reinforced through communication. For five of the informants ten years out, their identities are strongly tied to their religious beliefs, attitudes, and practices. For BK and DJ, the event was seen as an opportunity to share the gospel. Through leadership and teaching, BK and DJ have come to determine that events like this happen and it is a 
catalyst or invitation to seek Christ. BK said - Fo be comforted in knowing that he has all the control and to trust" (16). They held on to their strong Christian identities and further developed over the next ten years. For EC \& AR not only do they attend 180 Church, they also work and volunteer for $180 \_$s Church nonprofit organization. They identify themselves as followers of Christ and led by example for the younger generation, according to AR. GJ attends 180 Church and found Christ two years ago (2010). She spoke about how she loves coming to church on weekends to help the 180 Church in various activities and projects. For the three others currently members of the 180 Church, 9/11 did not directly affect their Christian beliefs and while two informants no longer attend church, neither attribute that to September $11^{\text {th }}, 2001$.

The study revealed a complex and still-present experience of terror, fear and changes in life due to the event. Everyone has their story to tell about what happened around them during 9/11. The relationship between the event and the impact on people's lives are undeniable. It is interesting that I had a unique opportunity to investigate the lived experiences of a specific population, and how they understood 9/11 then and now. The interviews were personal and in some cases, the participants have not shared their stories or thoughts about $9 / 11$ with anyone in years or on this specific level. The church members that I had not seen or spoken with in years, in some cases ten years, disclosed some rather personal information with me.

Although the event occurred over ten years ago, the impact it has had on these particular informants were life-changing and I was surprised by some of the responses I received from the informants. I found AR and NY's particular statements to be very 
powerful. They expressed their anger and reactions to 9/11. I have known AR for more than ten years and I would never imagined AR considering joining the army because of the impact of $9 / 11$. He told me in the interview, that he never told anyone else before about his thoughts of joining the army. He was so angry when it happened and how it took such a toll on his family business. AR 4 think for me it (9/11) was more like anger...for me, I couldn't believe someone could do something like that. It's like someone invading your own home. Just stealing something...That's what it (9/11) felt like. Your principles were taken away almost...it was just a big scale compared to other events" (7-8).

NY also had serious thoughts of joining the army because of the attacks. I find this particular idea to be extremely powerful and meaningful because their lives could have been different if they joined the army. NY also ended up dropping out of high school to gain income for the family after 9/11. One of his identity features as a high school student was no longer valid. How he understands 9/11 after ten years, I would argue, is affected by him no longer being in New York City after 9/11 took place. Throughout the interview, NY reflected how it has been eight years since he was in New York City and how he does not know what ground zero' looks like. Although after 9/11, I have never been back to the site where it was...so I never knew what it looked like back then...even what it looks like now...I think it would be interesting to revisit the place" (17).

I would argue that everyone has their own story to tell about $9 / 11$, such as where they were and what took place during that chaotic day. The study reflects my interest, 
involvement, and personal commitment to 9/11 and the Korean American community. In any given disaster, people are exposed to different aspects of the event and people relate and talk about their experiences with others. September 11, 2001 and peoples stories have become part of public memory. Zipporah Yamamoto (2011) writes about importance of 9/11 and its transformation of memory into history. He argues that any stories dealing with 9/11 are not only a part of a larger narrative history about the day that the U.S. was attacked, but also a part of a larger discourse on religion and its connections to crisis communication. Russell (2001) further adds these 9/11 personal narratives are a viable means to keep American's memory of that day alive and therefore they are rhetorically an interesting and multi-faceted way of constructing public memory" (p. 8).

\section{Research Expectations}

It is worth mentioning the research expectations that were and were not fulfilled in this study. (See Chapter 2) To my surprise, most of my expectations were not met. This was not a longitudinal study and the interpretations are from one time interviews; thus, timing and location of the interviews were some of the main considerations because I wanted the informants to feel comfortable in the interview settings and did not want length of time to become an issue. Yes, I interviewed eight former Marn Baek Sung members, but none of the interviews took place at Marn Baek Sung church as planned. Aside from the interview conducted at a home in Portland, Oregon, I thought that all remaining interviews would take place at the church we grew up in, but this turned out not to be the case. Five of the seven interviews in New York City took place at either the 180 Church headquarters or at the 180 Church itself. 180 Church is a new church that 
most of these second generation Korean-American informants attend. The remaining two interviews took place in informant's homes.

I presumed the informants would have much to share and planned for an interview time of more than one hour. The total interview time averaged more than an hour each; however several interviews were shorter than expected. Using a semistructured interview guide and probing questions during the interviews, I am confident that the actual amount of interviewing time is not an issue and sufficient data were collected for saturation to occur (Mason, 2010). Knowing ahead of time that this topic could be seen as sensitive, I expected some form of negative emotions during the interviews and I thought some informants might have a negative reaction to my thesis topic. To my surprise, not only did the informants complete the interview, but they were all in good spirits after the interview was completed. Each informant thought the resource contact sheet was not needed (See Appendix C). A few informants thought that the contact sheet was a joke and laughed when I presented them with it at the end of the interview. NY remarked Seriously? I don't need it, thanks though” (32).

I contacted each informant two weeks after the interview took place either by email or a phone call. I did this for several reasons. The first was to make sure I did not leave the informants hurt in any mental, emotional, or physical way during or after the interview process. All eight informants assured me that they were not harmed in any way from the study. NY reflected it (the interview process) was pretty straight forward. I just don't think I have much to say or have already talked about it before” (20). DJ said $\mathrm{It}$ 
was great seeing you the past few weeks. Great subject and interesting study my man! You know my info and know where I live for anything else!” (30).

Second, to strengthen trustworthiness of the study, I wanted to make sure that I could gather as much information as possible while the topic was still relevant. I felt that two weeks was enough time for the informants to reflect upon on the interview and the topic. During the follow up contact I asked them if I may have missed anything during the or after the interviews. As ER commented, $\mathrm{fmmm}$...that pretty much covers it all. I don't think I have anything else really" (21). RK responded yeah the research and topic make total sense. It's a cool project! I don't have anything else in mind so far” (20).

The third reason to contact the informants was to simply thank them again for their time and effort. I thanked the informants for their energy and willingness to meet with me and sharing some very personal information. I reminded the informants that they would not receive anything in return for their services, other than a copy of the thesis if they selected that option (See Appendix A).

A final expectation that was not met was that a special church service dedicated to the anniversary of $9 / 11$ would be held, Sunday, September 11, 2011. To my surprise it was just a regular" Sunday service at 180 Church, with the pastor briefly mentioning the significance of the date and the hope that traffic did not bother the congregation coming into the city. It is important to note that I did not attend any services at Marn Baek Sung church while in New York City, therefore I do not actually know if there were any special services at that church dedicated to the anniversary of 9/11. 
I chose to attend 180 Church's services while in New York City for two main reasons; sampling purposes and participate observation. I wanted to focus on the informant location during the anniversary and found that for those who still did attend church in New York City, they attended 180 Church. I knew that Marn Beak Sung did not have any college/ young adult services, and therefore by, attending 180 Church, it improved my chances of finding potential informants. The second reason to attend 180 Church was to become familiar again with the informants and the 180 congregation. I wanted to be involved and active in the church while visiting to not only become familiar again with the informants, but to also spend time reflecting on my childhood with the church friends I grew up with. The 180 Church is an important element in this study. It was towards the end of the data collection that I realized 180 Church is a prime example of the new wave of second generation Korean-American churches that Ahn (2004) and Kim (2010) are referring too. Spending time with the informants outside of the interviews, allowed me to gather a better understanding of how each informant lived the pass ten years and how 9/11 impacted their life.

\section{LIMITATIONS}

There are several limitations to the study. Due to the fact that I was trying to gain a better understanding of a particular group of people under certain circumstances, the responses may not reflect the larger population. My sample population was very unique and as previously outlined, had to fit a certain criteria. The demographics of the interview participants are very specific and may not represent the larger Asian community in New 
York City. Thus, as a qualitative researcher, I assume that the study may not be generalizable to the larger population. I thought that each interviewee was a second generation Korean American native New Yorker, which turned out not to be the case. DJ was technically born in South Korea and moved to the US at age four. AR was born in Colorado and moved to New York City at age two. The remaining six informants were born in New York City. Related limitation was the total number of interviews conducted. I only conducted eight interviews and the thesis is based on those interviews. It may be possible that the lived experiences of other second generation Korean-American Christians who were adolescents during 9/11 was not the same as those I interviewed. However, the goal was to understand, from the respondent's perspective, how these particular participants made sense of reality at the time of $9 / 11$.

Another limitation was not gathering more data on coping. It may have been helpful to rephrase the question or ask additional probing questions. Perhaps future research can investigate more on coping with terrorist attacks.

Another limitation that was acknowledged towards the end of the study was the need to ask more questions that related to religion. By asking more questions, it would have strengthened the study and yielded more data on 9/11 and people's religious beliefs.

The last limitation was memory decay (Sims \& Gray, 2004). It is worth mentioning that time was a factor in the study, which does not mean the narratives and stories told are not valid or less important. It was apparent that length of time from the original event affected some recall of $9 / 11$. That is, some participants felt like they were 
not able to remember some details from ten years ago. I found it difficult at times to take the participants back ten years and assist their recreating their experience. RK Man ten years ago...I can't really remember what happened to be honest" (16). AR it was confusing times..I can't recall too much detail, been a while” (3). EC I'm trying to remember...ten years...it's a long time to think about that" (10).

\section{CONTRIBUTIONS}

This phenomenological study is one of the first qualitative studies to investigate the lived experiences of the cultural sharing group of second generation KoreanAmericans living in New York City at the time of 911. I sought to understand from their perspectives, the phenomena of 9/11 and the impact it had on their lives and religion. This study contributes to a growing body of new research about this particular ethnic group. This study provided an opportunity to see and understand what is being communicated about $9 / 11$, it's anniversary, and its ties to religion. The strength of the research is that I have the stories and direct quotes from a specific group of individuals about how they experienced 9/11, its impact on their religious beliefs, and what 9/11 means to them after a decade. This study is the first of its kind and is unique in that no one has asked these questions to this specific ethnic group. There has been very little research on Korean American Christians and since 9/11, I have only been able to find one document that links directly to the research topic, that is, Heerak Kim's work KoreanAmerican youth identity and 9/11". This study fills in some gaps and in-depth meaning for this specific population. 


\section{FUTURE RESEARCH}

The research approach I used can be applied to other Asian American groups to be studied and how 9/11 affected their lives and religious positions. For comparative purposes, the research process is detailed, that is, an explicit paper of the research process was kept and could be used and further developed in future studies. Although this study focused on second generation Korean-American Christians, future research can be applied to Korean-Americans with different religious backgrounds, such as Buddhist and Catholic. No other religious groups were mentioned in the interviews.

BK talked about how, with this type of research, we can better understand behaviors of Asian Americans when crisis situations occur. When in crisis and in moments of doubt... And you know I was just hoping, through your research your doing, we can better see what behaviors Asian Americans, like second generation kids, go through, when and the type of crisis that occurs. Can that be a window of opportunity to discuss about faith?” (19). As Hawkins (2011) notes Especially with the increased likelihood of terrorist attacks in the U.S., we must advance research that is sensitive to the experience of victims of mass violence so as to provide consistent and genuinely helpful assistance in its wake" (pg, 199).

\section{CONCLUDING REMARKS}

In the manhunt to find and capture the mastermind behind September $11^{\text {th }}, 2001$, on May 2, 2011, Osama Bin Laden was found and killed by U.S. Navy Seals in Abbottabad, Pakistan. His death comes at a significant time in history, in that he was 
discovered just prior to the tenth year anniversary of $9 / 11$. When news broke of Bin Laden's death, I quickly thought about the painful memories of September $11^{\text {th }}$, 2001. I realize after the completion of the study and through the writing process, that my journey to find these questions I have thought about for years, reflect upon my own questions about 9/11 and how it changed my life and religious beliefs. The impact of the event has different meanings for different people. To the people that were directly affected by the attacks, the changes have been concrete: loss of a family member, loss of a job, loss of property, and loss of life. I argue that to those that were not directly affected, 9/11 has had more of an abstract impact.

In either case, what occurred defined a generation of Americans who witnessed the events. This was an exploratory research study, traveling from one end of the U.S. to the other end to interview previous church friends about their religious point of view. I went outside my comfort zone to honestly ask people who I had not seen in several years, to take time out of their day, to participate in an in-depth interview on an emotional subject. The stories that I have heard during the process of interviewing will always be a part of 9/11 history. Understanding my own point of view, not only a researcher, but also as a member of this unique group of individuals has been meaningful as I examined the construction of personal narratives given by individuals who were in New York City when $9 / 11$ occurred. My personal journey continues beyond the thesis. I hope that I that represented the informants and Marn Beak Sung church well and that I presented the informants stories in the manner which justifies and honors their point of view. 


\section{REFERENCES}

Ahn, S. J. (2000). Putting the American“ into _Korean-American': the social identity of a second generation. Retrieved from ProQuest Dissertations.

Babbie, E. (1995). The practice of social research $\left(7^{\text {th }}\right.$ ed.). Belmont, CA: Wadsworth.

Barna Group. (n.d.). How America's Faith had Changed Since 9/11. Retrieved from http://www.barna.org/barna-update/article/5-barna-update/63-how-americas-faith-haschanged-since-9-11

Bogden, R., \& Biklen, S. (1992). Qualitative research in education (2 ${ }^{\text {nd }}$ ed.). Boston; Allyn \& Bacon.

Bond, J. (2002). Reflections on 9/11: why race, class, gender, and religion matter. Philosophia Africana. 5 (2).

Bruner, J. (1990). Acts of Meaning. Cambridge, MA: Harvard University Press.

Capps, L. \& E. Ochs. (1995). Constructing Panic: The Discourse of Agoraphobia. Cambridge: Harvard Univ. Press.

Chong, K. (1998). What it Means to be Christian: The Role of Religion in the Construction of Ethnic Identity and Boundary among Second Generation Korean Americans.” Sociology of Religion. 59(3), pp. $259-86$.

Convenience Sampling. (2002). Retrieved from

http://changingminds.org/explanations/research/sampling/convenience_sampling.htm

Davis, O., Martin, J. N., \& Nakayama, T. K. (2000). Current and future directions in ethnicity and methodology. International Journal of Intercultural Relations. 24 (5). pp. 525-539.

Easton, K. L., McComish, J. F., \& Greenberg, R. (2000). Avoid common pitfalls in qualitative data collection and transcription. Qualitative Health Research, 10, 703-708.

Faith. (n.d.). Retrieved from www.merriam-webster.com/dictionary/faith

Foner, N. (2005). Wounded City: the social impact of 9/11. Russell Sage Foundation. Retrieved from http://books.google.com/books?hl=en\&lr=\&id=Y2Jod7xIaHYC\&oi=fnd\&pg=PR7\&dq=r eligion + impact + on $+9 / 11$ \&ots $=1 \mathrm{cBSJ}$ sUOIN\&sig=QstLn5CHn0LZ6smpXb1j4I8mn3o\#v $=$ onepage $\& \mathrm{q}=$ religion $\% 20 \mathrm{impact} \% 20 \mathrm{on} \% 209 \% 2 \mathrm{~F} 11 \& \mathrm{f}=\mathrm{false}$ 
Gallup Organization. (2001). Retrieved on April 6, 2011.

http://www.gallup.com/poll/5134/Religion-Aftermath-September.aspx.

Groenewald, T. (2004). A phenomenological research design illustrated. International Journal of Qualitative Methods, 3(1).

Grossman, C, L. (2002). Study: 9/11 did little to shake spiritual complacency“. USA Today.

Hawkins, A., McIntosh, D, N., Silver, R, C, \& Holman, E, A. (2004). Early Responses to School Violence: A Qualitative Analysis of Students' and Parents 'Immediate Reactions to the Shootings at Columbine High School. The Haworth Press, Inc. pp. 197-223.

Healey, S. (2005). Religion and terror: a post-9/11 analysis. International Journal on World Peace, 24 (3), pp. 3-22. Retrieved from ProQuest Digital Dissertations.

Heider, F. (1958). The Psychology of Interpersonal Relations. New York: Wiley.

Hoffman, J. (2007). The Crash of Flight 93. Retrieved from http://911 review.com/attack/flights/f93.html

Husserl, E. (1962). Ideas: General introduction to pure phenomenology. New York: Collier Books.

Hycner, R. H. (1999). Some guidelines for the phenomenological analysis of interview data. In A. Bryman \& R.G. Burgess (Eds.), Qualitative research, 3, pp. 143-164). London: Sage.

Juergensmeyer, M. (2004). Thinking about religion after 9/11. Journal of the American Academy of Religion, 72 (1).

Kelley, H. H. (1971) Attribution in social interaction. New York. General Learning Press.

Kirk, J., \& Miller, M., (1986). Reliability and Validity in Qualitative Research. Qualitative Research Methods Series 1. Sage Pubs, CA

Kim, H.C. (2008). Korean-American youth identity and 9/11. The Hermit Kingdom Press.

Kim, S. (2010). Shifting boundaries within Second-Generation Korean American Churches. Sociology of Religion, 71 (1).

King, N. (1994). The qualitative research interview. In C. Cassell \& G. Symon (Eds.), Qualitative methods in Organizational research: A practical guide. London: Sage. 
Krauss, S, E. (2005). Research Paradigms and Meaning Making: A Primer. The Qualitative Report, 10(4), pp. 758-770.

Lauer, Q. (1958). Phenomenology: Its genesis and prospects. New York: Harper.

Lester, S. (1999). An introduction to phenomenological research,' Taunton UK, Stan Lester Developments. Retrieved from www.sld.demon.co.uk/resmethy.pdf

Levin, S. (2006). For most of us, life after $9 / 11$ still very much the same. Retrieved from http://www.post-gazette.com/pg/06253/720611-84.stm

Lincoln, Y. S., \& Guba, E. G. (1985). Naturalistic Inquiry. Beverly Hills, CA: Sage Publications, Inc.

Lindlof, T, R. \& Taylor, B, C. (2002). Qualitative communication research methods. SAGE publications.

Lofland, J., \& Lofland, L. H. (1999). Data logging in observation: Fieldnotes. In A. Bryman \& R. G. Burgess (Eds.), Qualitative research (3). London: Sage.

Luborsky, M. (1994). The identification and Analysis of Themes and Patterns. In Jaber F. Gubrium \& Andrea Sankar (eds.) Qualitative Methods in Aging research. Thousand Oaks, CA: Sage

Luminet, O. \& Curci, A. (2009). Flashbulb memories. New issues and new perspectives. Psychology Press.

Mason, M. (2010). Sample Size and Saturation in PHD studies. Using Qualitative Interviews. 11 (3).

Maxwell, J. (2005). Qualitative Research Design: An Interactive Approach. Second Edition. Thousand Oaks, CA: Sage

Miller, C. (2002). September 16. Prime Media Magazine [New York], 54.

McCracken, G. (1988). The Long Interview: Qualitative Research Methods Series. (13). Newbury Park, CA: Sage

Mouton, J. \& Marais, H.C. (1990). Basic Concepts in the Methodology of the Social Sciences (Revised ed.). Pretoria, South Africa: Human Sciences Research Council.

NYC Victims. (2007). Who was killed in the 9/11/01 attack on New York City. Retrieved from http://911 research.wtc7.net/sept11/victims/nyckilled.html

Osborne, J. (1994). Some similarities and differences among phenomenological and othermethods of psychological qualitative research. Canadian Psychology, 35(2), 167189. 
Palacio, G. (2005). Adolescent narrative responses to September $11^{\text {th }}$ : A qualitative investigation into meaning making, trauma, and themes revealed in parent and young adult narratives. Retrieved from ProQuest Digital Dissertations.

Pargament, K. I. (1997). The psychology of religion and coping. New York: Guilford.

Patton, M. (2002). Qualitative Research \& Evaluation Methods $3^{\text {rd }}$ edition. Thousand Oaks, CA: Sage.

Pew Research Center (2001). Retrieved from http://people-press.org/2001/12/06/postseptember-11-attitudes/

Philip. (2009). Remembering the Asian American victims of 9/11. Retrieved from http://youoffendmeyouoffendmyfamily.com/remembering-the-asian-american-victimsof-911/

Poland, S., \& McCormick, J. S. (1999). Coping with Crisis: A resource for schools, parents, and communities. Colorado, Sopris West.

Posta, E. (2010). The narrative process and the stories of family member who lost loved ones on 9/11. Retrieved from ProQuest Digital Dissertations.

Praetorius, D. (2012, September 11). How social media would have changed New York on 9/11. Retrieved from http://www.huffingtonpost.com/dean-praetorius/social-media-911-new-york b 1872764.html

Reardon, M. (2011). Post 9/11: Can we count on cell networks? Retrieved from http://www.cbsnews.com/2100-503063_162-20102573.html

Religion. (n.d.). In Dictionary online. Retrieved from http://dictionary.reference.com/browse/religion

Russell, J. (2001). Molding the past: The Rhetoric and construction of memory in everyday life. Retrieved from ProQuest Digital Dissertations.

Sadala, M. L. A., \& Adorno, R. F. (2001). Phenomenology as a method to investigate the experiences lived: A perspective from Husserl and Merleau-Ponty's thought. Journal of Advanced Nursing, 37(3), 282-293.

September 11, 2001. In Encyclopedia online. Retrieved from http://www.encyclopedia.com/topic/9-11.aspx

Stanfield, J. H., (2011). Rethinking Race and Ethnicity in Research Methods.

Schurink, W. J., Schurink, E. M. \& Poggenpoel, M. (1998). Focus group interviewing and audio-visual methodology in qualitative research. In A. S. De Vos (Ed.), Research at grass roots, a primer in care professions. Pretoria, South Africa: Van Schaik. 
Spilka, B, Shaver, P, \& Kirkpatrick, L.A. (1985). A general attribution theory for the psychology of religion. Journal for the Scientific Study of Religion, 24(1), 1-20.

Takaki, R. (2001). From a different shore. In M. Zhou \& J. Gatewood (Eds.), Contemporary Asian America: A Multidisciplinary Reader. New York: New York University Press.

U.S. Bureau of the Census. (2001). 2000 Census of Population, Profile of General Demographic Characteristics (DP-1).

Van Manen, M. (1984). Đoing" phenomenological research and writing. Alberta: University of Alberta Press.

Van Manen, M. (1990). Researching lived experience: Human science for an action sensitive pedagogy. Althouse Press: London: Ontario, Canada.

Van Manen, M. (1997). Researching lived experience: Human science for an action sensitive.

Welman, J. C., \& Kruger, S. J. (1999). Research methodology for the business and administrative sciences. Johannesburg, South Africa: International Thompson.

Wertz, F J (2005) Phenomenological research methods for counseling psychology, Journal of Counseling Psychology, 52(2), 167-177.

Yamamoto, Z. (2011). After 9/11: Transformations of memory into history. Retrieved from ProQuest Dissertations. 


\title{
APPENDIX A
}

\section{Preliminary Questions/ Interview Guide}

\author{
For Qualitative research project
}

\section{Today's Date:}

Place:

Time:

Interviewer's Name:

Participant's Name:

Age:

Birth place:

Born in, resided in:

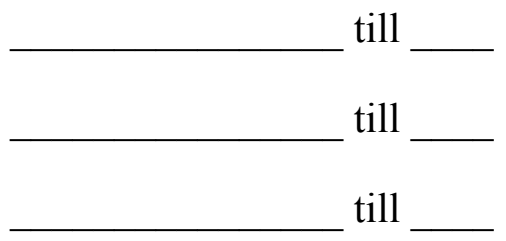

Ethnic background:

Occupation:

Current address:

Where were you at the day of $9 / 11$ ?

Can you recall what you did at the time?

What were your thoughts and impressions at the time of the attack?

What was life like in the days after the event?

What did 9/11 mean to you then? Now? 
What impact did 9/11 have on people‘s religious faith at that time? What about you?

In what ways did you cope with the event?

Did the event have an effect on your spiritual well being?

Would you say you received closure for the event? If yes, how so? If no, why not?

Were there any social benefits as a result of $9 / 11$ then? What about now?

Now ten years later, what is your religious position like today? Has it changed since $9 / 11 ?$

What did you do on the anniversary day? Any specific plans? (i.e. behavior, practices.)

Was there anything I may have missed or you would like to add?

Do you have any questions for me? 


\section{APPENDIX B}

\section{Informed Consent}

Standard ethics protocol

(To be read by interviewer before the beginning of the interview. One copy of this form will be left with the respondent, and one copy will be signed by the respondent and kept by the interviewer).

Hi, my name is Jay Lee. I am conducting research on a project entitled: Life post9/11: Experiences of Korean Americans ten years later.

Thank you for your willingness to participate in this research project. Your participation is very much appreciated. Just before we start the interview, I would like to reassure you that as a participant in this project you have several very definite rights.

First, your participation in this interview is entirely voluntary.

You are free to refuse to answer any question at any time.

You are free to withdraw from the interview at any time.

This interview will be kept strictly confidential and will be available only to member of the research team.

Excerpts of this interview may be made part of the final research report, but under no circumstances will your name or identifying characteristics be included in this report.

I would be grateful if you would sign this form to show that I have read you its contents and for permission to tape record the interview.

(signed)

(printed)

(dated)

Please send me a report on the results of this research project. (circle one)

Address for those requesting research report

This project is being sponsored by the Department of Communication studies at Portland State University. I am the principal investigator of this project and I may be contacted at this phone number or email address should you have any questions. 
(Interviewer: keep signed copy; leave unsigned copy with respondent.) 


\section{APPENDIX C}

Contact information for help.

The National Center for Victims of Crime. Provide several solutions to families of trauma victims. Support center. Can call 1-(800)-fyi-call or email gethelp@ncvc.org-

The World Trade Center Survivors Network at- contact@survivorsnet.org. This non-profit, non-political group employs a wide range of activities and initiatives to serve 9/11 survivors. http://www.survivorsnet.org/

www.911memorial.org - a website where victims of 9/11 can share and post their stories. They can be contacted at (212)-312-8800 or at info@national911memorial.org 